\title{
Molecular Mechanistic Pathways Targeted by Natural Antioxidants in the Prevention and Treatment of Chronic Kidney Disease
}

\author{
Mohamed Mohany *(1), Mohammed M. Ahmed (1) and Salim S. Al-Rejaie \\ Department of Pharmacology and Toxicology, College of Pharmacy, King Saud University, \\ Riyadh 1145, Saudi Arabia; mmahmed114@yahoo.com (M.M.A.); rejaie@ksu.edu.sa (S.S.A.-R.) \\ * Correspondence: mmohany@ksu.edu.sa
}

Citation: Mohany, M.; Ahmed, M.M.; Al-Rejaie, S.S. Molecular Mechanistic Pathways Targeted by Natural Antioxidants in the Prevention and Treatment of Chronic Kidney Disease. Antioxidants 2022, 11, 15. https:// doi.org/10.3390/antiox11010015

Academic Editors: Natalia Di Pietro and Mario Bonomini

Received: 8 November 2021

Accepted: 17 December 2021

Published: 22 December 2021

Publisher's Note: MDPI stays neutral with regard to jurisdictional claims in published maps and institutional affiliations.

Copyright: (C) 2021 by the authors. Licensee MDPI, Basel, Switzerland. This article is an open access article distributed under the terms and conditions of the Creative Commons Attribution (CC BY) license (https:// creativecommons.org/licenses/by/ $4.0 /)$.

\begin{abstract}
Chronic kidney disease (CKD) is the progressive loss of renal function and the leading cause of end-stage renal disease (ESRD). Despite optimal therapy, many patients progress to ESRD and require dialysis or transplantation. The pathogenesis of CKD involves inflammation, kidney fibrosis, and blunted renal cellular antioxidant capacity. In this review, we have focused on in vitro and in vivo experimental and clinical studies undertaken to investigate the mechanistic pathways by which these compounds exert their effects against the progression of CKD, particularly diabetic nephropathy and kidney fibrosis. The accumulated and collected data from preclinical and clinical studies revealed that these plants/bioactive compounds could activate autophagy, increase mitochondrial bioenergetics and prevent mitochondrial dysfunction, act as modulators of signaling pathways involved in inflammation, oxidative stress, and renal fibrosis. The main pathways targeted by these compounds include the canonical nuclear factor kappa B (NF-kB), canonical transforming growth factor-beta (TGF- $\beta$ ), autophagy, and Kelch-like ECH-associated protein 1 (Keap1)/nuclear factor erythroid factor 2-related factor 2 (Nrf2)/antioxidant response element (ARE). This review presented an updated overview of the potential benefits of these antioxidants and new strategies to treat or reduce CKD progression, although the limitations related to the traditional formulation, lack of standardization, side effects, and safety.
\end{abstract}

Keywords: chronic kidney disease (CKD); diabetic nephropathy; renal fibrosis; natural compounds; mechanistic pathways

\section{Introduction}

Chronic kidney disease (CKD) is a significant public health concern, affects about 500 million people worldwide [1]. The pathogenesis of CKD includes several variables and steps, but the exact mechanism is still unknown. CKD pathogenesis's leading and fundamental cause is linked to oxidative stress [2]. Fibrosis, tubulointerstitial inflammation, and glomerulosclerosis are structural changes seen in CKD patients' glomeruli and tubular cells [3] The progression of CKD may advance to renal failure, and in that case, dialysis or kidney transplantation might be urgent and required [4].

Phytochemicals and other natural products are increasingly prevalent in promoting health and preventing various diseases, and they have been used in traditional and complementary medicine for many years [5]. Scientific researchers are looking for alternative treatments for CKD after seeing promising results from some clinical trials that used natural products or their isolated compounds [6,7]. The main potential therapeutic strategies in the management of CKD include modulation of the nuclear factor $B(N F-k B)$ signaling pathway [8], activation of autophagy, prevention of mitochondrial dysfunction [9], activation of the nuclear factor erythroid 2-related factor 2 (Nrf-2) pathway, and inhibition of the transforming growth factor $\beta$ (TGF- $\beta$ ) signaling pathway [10]. We searched scientific sources and article indexed databases, including PubMed and Google Scholar, by different keywords, including CKD, diabetic nephropathy; renal fibrosis; natural compounds; 
mechanistic pathways. This article reviews the most recent literature from animal models, in vitro, and clinical studies regarding the impact of antioxidants in the prevention and treatment of CKD. Although, natural antioxidant compounds have been shown to have protective benefits against CKD [11-13]. The molecular mechanisms by which these natural products and plant-derived compounds exerted their kidney-protective effects have yet to be identified. This article provides an overview of the role of different mechanistic pathways associated with CKD pathogenesis and the potential utility of targeting these pathways by natural antioxidants in the treatment of CKD. The selection criteria for these natural compounds were based on their favorable outcomes in preclinical and clinical research, as well as the fact that they were not covered in previous reviews, particularly the molecular pathways. This review identifies flaws in our present understanding of alternative therapies for chronic renal disease and areas where more research is needed. This is not a traditional literature review, but rather an eye-opening document meant to urge academics, particularly physicians, to conduct further research in this field.

\section{Signaling Pathways That Predispose to the Progression of CKD}

\subsection{NF-kB Pathway}

CKD is characterized by a state of systemic inflammation that contributes to CKD progression [14]. Multiple receptors are involved in precipitating chronic inflammatory renal injury, including Toll-like receptor 4 (TLR4) and tumor necrosis factor receptor 1 (TNFR-1) [15]. TLR4 is a pattern recognition receptor involved in the direct and indirect activation of the nuclear factor $\mathrm{kB}(\mathrm{NF}-\mathrm{kB})$, the master regulator of inflammatory pathways [16]. It is pathologically activated in CKD through different ligands that are produced as a result of progressive renal tissue injury [17]. These ligands include high-mobility group box 1 (HMGB1), heat-shock proteins (HSPs), and components of the extracellular matrix $[18,19]$. Stimulation of TLR4 activates the adapter protein myeloid differentiation primary response 88 (MyD88), leading to the recruitment of interleukin-1 receptor-associated kinase 4 and 1 (IRAK 4/1) [20]. Consequently, IRAK 4/1 recruits TNF receptor-associated factor 6 (TRAF6), which in turn activates the NF- $\mathrm{KB}$ essential modulator (NEMO) complex, ultimately resulting in the nuclear translocation of NF- $\mathrm{kB}$ [21]. In the nucleus, NF- $\mathrm{kB}$ binds to specific $9-10$ base pair, $\mathrm{KB}$ sites, thus activating the transcription of inflammatory mediators including TNF- $\alpha$, interleukin $1 \beta$ (IL-1 $\beta$ ), interleukin 6 (IL-6), and monocyte chemoattractant protein 1 (MCP1) [22]. The inflammatory cytokines attract macrophages, which in turn secrete TNF resulting in the activation of TNFR-1 that recruits the scaffolds tumor necrosis factor receptor type 1-associated death domain (TRADD) and TNF receptor-associated factor 2/5 (TRAF 2/5) [23]. Therefore, TNFR-1 downstream signaling can activate apoptosis through recruitment of Fas-associated death domain (FADD) and activation of caspase-8, it can also induce the nuclear translocation of NF- $\mathrm{KB}$ through activation of the NEMO complex, further aggravating renal inflammatory injury [24].

\subsection{Autophagy}

One of the hallmarks of CKD is impaired autophagic flux, which is protective in renal disease [25]. Autophagy is activated in response to the accumulation of reactive oxygen species (ROS) and starvation [26]. Two main complexes are involved in the initiation of autophagy, class 3 phosphoinositide 3-kinase (PI3K) complex, which includes Beclin-1, and Unc-51-like kinase 1 (ULK-1) complex [27]. The class 1 PI3K suppresses ULK-1 by activating the mammalian rapamycin (mTOR) target, leading to a reduction in autophagic flux [28]. CKD is associated with an increase in the expression of microRNA-21 (MiR-21), which negatively regulates phosphatase and tensin homolog (PTEN) [29]. PTEN negatively regulates the class $1 \mathrm{PI} 3 \mathrm{~K}$; thus, the abundance of MiR-21 associated with CKD results in the inhibition of the ULK-1 complex and reduction in autophagic flux [30]. The second phase of autophagy involves the conversion of microtubule-associated proteins $1 \mathrm{~A} / 1 \mathrm{~B}$ light chain 3B-I (LC3-I) to microtubule-associated proteins 1A/1B light chain 3B-II (LC3-II) to drive the elongation of autophagosome [31]. 


\subsection{Mitochondrial Dysfunction}

Mitochondrial dysfunction is a leading event contributing to CKD progression [32]. In diabetic nephropathy, hyperglycemia leads to an increase in the adenosine triphosphate (ATP) to adenosine monophosphate (AMP) ratio, a consequence of an elevation in nutrient availability that is associated with the diabetic milieu [33]. This increase in the level of ATP is attributed to an increase in oxidative phosphorylation, leading to a reduction in AMP and consequent inactivation of AMPK [34]. Similarly, excessive levels of circulating free fatty acids (FFA) activate renal CD36 leading to the inactivation of AMPK [35]. Hyperglycemia is also linked to a reduction in the NAD ${ }^{+}$to NADH ratio due to increased electron transport chain activity related to the abundance of nutrients [36]. The reduced $\mathrm{NAD}^{+}$levels lead to the inactivation of class III histone deacetylases the NAD ${ }^{+}$-dependent sirtuins [37]. These events coalesce to reduce the level of PGC1- $\alpha$, the master regulator of mitochondrial biogenesis, leading to diminished mitochondrial biogenesis and mitochondrial dysfunction [38]. Dysfunctional mitochondria attract cytosolic dynamin-related protein1 (Drp1), which leads to excessive mitochondrial fission and mitochondrial fragmentation [39]. In addition, mitochondrial dysfunction leads to excessive fatty acid deposition due to the reduction in fatty acid oxidation [40]. Moreover, excessive ROS is released to the cytosol and mitochondrial apoptogenic factors leading to renal cell death [41].

\subsection{Nrf-2 Signaling Pathway}

The diabetic milieu is associated with the excessive activation of insulin and insulinlike growth factor-1 (IGF-1); this leads to phosphorylation of insulin receptor substrate 1 (IRS-1) [42]. Phosphorylated IRS-1 acts as an adapter protein that phosphorylates PI3K, which in turn converts phosphatidylinositol 4,5-bisphosphate (PIP2) to phosphatidylinositol 3,4,5-triphosphate (PIP3) [43]. PIP3 exposes a pleckstrin-homology domain that recruits the inactive protein kinase B (thereafter referred to as Akt), which is then activated and leads to the inhibition of glycogen synthase kinase $3 \beta$ (GSK-3 $\beta$ ), an enzyme involved in apoptosis [44]. One of the effects of active GSK-3 $\beta$ is the inhibition of the nuclear translocation of the nuclear factor erythroid 2-related factor 2 (Nrf-2); thus, its inhibition by Akt results in an increase in Nrf-2 dissociation from Kelch-like ECH-associated protein 1 (Keap-1) that is holding Nrf-2 in an inactive state in the cytosol [45]. The reduced levels of AMPK contribute to an increase in Keap-1-Nrf-2 complex and a reduction in binding of Nrf-2 to the antioxidant response element and transcription of antioxidant enzymes, including heme oxygenase-1 (HO-1), super oxide dismutase (SOD), catalase (CAT), and glutathione peroxidase (GPx) [46]. In addition, the inflammatory milieu related to CKD leads to reduced Nrf-2 transcriptional activity and renal antioxidant capacity [47].

\subsection{TGF- $\beta$ Signaling Pathway}

Renal fibrosis is the last stage of CKD, characterized by tubulointerstitial fibrosis and glomerulosclerosis [48]. Transforming growth factor- $\beta$ (TGF- $\beta$ ) is a critical mediator of renal fibrosis [49]. In a variety of cell types, activated TGF- $\beta$ binds to transforming growth factor-beta receptor (TGF- $\beta$ R), triggering an intracellular phosphorylation cascade involving the transcription factors mothers against decapentaplegic homolog 2 (SMAD2) and mothers against decapentaplegic homolog 3 (SMAD3) [50]. SMAD 2/3 complex with the common SMAD (SMAD4) translocates into the nucleus, leading to pro-fibrotic genes including collagen 1 and fibronectin that make up the extracellular matrix, proteins that are involved in epithelial to mesenchymal transition, and pro-fibrotic miRNA [51]. SMAD7, the inhibitory regulator in the TGF- $\beta /$ SMAD signaling pathway, inhibits the activation of SMAD 2/3 via its negative feedback mechanism [52]. SMAD 7 is negatively regulated by microRNA-21 (miR-21); therefore, SMAD7 could be a therapeutic approach for CKD treatment [53]. The advanced glycation end products (AGEs) and angiotensin II (ANG 2) drive the activation of mitogen-activated protein kinase (MAPKs) that activate the TGF$\beta /$ SMAD signaling pathway $[54,55]$. Nitric oxide $(\mathrm{NO})$ is also involved in inhibiting SMAD $2 / 3$ and is therefore used as a therapeutic target for treating fibrotic kidney diseases [56]. 


\section{Role of Antioxidants in the Prevention of CKD}

The critical therapies for CKD patients depend on which stage they are in. To treat symptoms of CKD, pharmacological therapy, changes in diet and lifestyle, dialysis, and kidney transplantation are used. In addition to traditional therapy, scientists concentrate on the recent use of dietary supplements and novel natural products or their derivatives to reduce the high risk of CKD and limit the severity of this disease. In this regard, numerous studies and reviews have documented the potential impact of compounds with anti-inflammatory and antioxidant activities in CKD treatment $[12,13,57,58]$. Other studies have indicated that dietary interventions are essential in lowering inflammation and oxidative stress in CKD patients [57].

\subsection{Medicinal Plants and Natural Compounds against CKD}

Some plant extracts have been investigated previously in the treatment of CKD due to their possible therapeutic properties [58-60]. In this regard, recent experimental studies investigated the effects of Phylanthus niruri leaves aqueous extract (PN) on renal functions, structural alteration, and biomarkers of oxidative stress, inflammation, fibrosis, apoptosis, and proliferation in the diabetes mellitus (DM) rat model. The data indicated that PN could maintain normal kidney function and amended histopathological changes by improving oxidative stress markers such as thiobarbituric acid reactive substances (TBARS), superoxide dismutase (SOD), catalase (CAT) and glutathione peroxidase (GPx), inflammatory markers (NFk $\beta$-p65, Ikk- $\beta$, TNF- $\alpha$, IL-1 $\beta$, and IL-6), apoptosis markers (caspase-3, caspase9 , and Bax), fibrosis markers (TGF- $\beta 1$, VEGF and FGF-1) and proliferative markers such as proliferating cell nuclear antigen (PCNA) and Ki-67 in diabetic nephropathy (DN) rat model [61]. The authors reside the therapeutic effects of PN extract to the occurrence of antioxidant and anti-inflammatory activities of specific bioactive compounds (palmitic acid and linoleic acid).

Renal tubulointerstitial fibrosis is the predominant common mechanism of progressive kidney injury, leading to end-stage renal disease (ESRD). Wu and colleagues (2018) demonstrated the in vivo and in vitro anti-fibrotic effects of total flavonoids (TFs) derived from leaves of Carya Cathayensis and explored the underlying mechanisms [62]. TFs of Carya Cathayensis have been found to reduce renal fibrosis through a signaling pathway miR$21 /$ Smad7, indicating their therapeutic function as an anti-fibrotic candidate. Additionally, it has been stated in a comprehensive review that flowers of Abelmoschus manihot (Linnaeus) Medicus (Malvaceae; Flos A. manihot) prevented the progression of CKD [63]. Data from in vivo studies in animal models of rabbits with glomerulonephritis [64], DN [65,66], and adriamycin-induced nephropathy $[67,68]$ have revealed that flavonoids of Flos A. manihot have renoprotective effects, which are shown by the ability to alleviate proteinuria, apoptosis of podocytes, glomerulosclerosis and mesangial proliferation via various mechanisms focused on inhibition of caspases, amelioration of oxidative stress, infiltration reduction, and suppression of the p38 MAPK and serine/threonine kinase (Akt) pathways, as well as TGF- $\beta 1$ and TNF- $\alpha$ expression. It has been documented in patients with glomerular disease that Flos A. Manihot was superior to losartan in proteinuria reduction [69].

Astragalus, the dried root of Astragalus membranaceus, is one of the most commonly used herbs for the treatment of kidney diseases in traditional Chinese medicine. There have been observations of many biological activities of Astragalus, including immunomodulatory [70], antioxidant [71], anti-inflammatory [72], and kidney protection [73].

In an in vitro model of oxidative stress, Shahzad et al. (2016) examined the renoprotective effect of ethanol, methanol, and aqueous crude extracts of roots of A. membranaceus on human kidney proximal tubular epithelial cells. The protective effect of $A$. membranaceus on renal damage related to anti-apoptotic and anti-inflammatory mechanisms [74]. Furthermore, it has been shown that $A$. membranaceus is capable of improving ischemic microvasculature and attenuating interstitial fibrosis by increasing NO output via eNOS activation and ROS scavenging in obstructed rat kidneys [75]. A. membranaceus treatment has been shown to alleviate kidney dysfunction by ameliorating serum creatinine, uric acid, sodium, 
and potassium levels in aged rats [76]. This treatment also preserved stable levels of eGFR and postponed the entrance in renal replacement therapy in patients with progressive CKD stage 4 [77]. Meta-analysis of the beneficial effect and the clinical value of $A$. membranaceus has shown that Astragalus therapy prevents the progression of DN and improves renal functions (BUN, SCr, CCr, and urine protein) and serum albumin levels in patients with DN $[78,79]$. Previous reports have been shown that treatment with Astragalus reduces proteinuria and enhances hemoglobin and serum albumin [59].

Recently, there is a commonly used formula of Astragalus mongholicus Bunge and Panax notoginseng (Burkill) F.H. Chen formula (APF) in China clinics for CKD treatment. It has been reported that this formula inhibits renal inflammatory injuries in DN by upregulation autophagy via suppressing mTOR and activating PINK1/Parkin signaling pathways [80]. Furthermore, Zuo et al. demonstrated that Astragalus mongholicus attenuated renal fibrosis in a rat model of unilateral ureteral obstruction (UUO) through the reduction in TGF- $\beta 1$ and $\alpha$-smooth muscle actin (alpha-SMA) expression [81]. Treatment by Astragalus mongholicus also improved the histopathological alterations comparable to the established renoprotective drug losartan. The same author reported that Astragalus mongholicus suppressed the transdifferentiation of renal epithelial tubular myofibroblasts halting the progression of renal interstitial fibrosis in the same model [82]. In another model of CKD, Astragalus mongholicus in combination with Angelica sinensis reduced renal fibrosis in chronic puromycin aminonucleoside-induced nephrosis by attenuating the expression of TGF- $\beta 1$ and impeding renal macrophages localization comparable to renin-angiotensinaldosterone system (RAAS) blockade by enalapril [83]. A gene microarray study revealed that Astragalus mongholicus fed DN mice had altered gene expression related to metabolism, immunity, and inflammation that positively impacted the disease state [84].

In eastern Asian countries, the azuki bean (Vigna angularis) is widely farmed and is considered one of the essential crops. The major constituents of Vigna angularis are the polyphenolic proanthocyanidins that are characterized by their ability to scavenge ROS [85]. In a recently published study, Vigna angularis administration mitigated kidney injury by increasing the expression of glutathione (GSH) and light chain 3B II (LC3B-II), as well as reducing the expression of heme oxygenase-1 (HO-1), p47phox (NADPH oxidase subunit), and p62/sequestosome 1 (p62) in STZ-induced DN rats [86]. An earlier study using the same model of DN demonstrated that treatment by seeds coats of Vigna angularis attenuated oxidative stress damage by reducing MDA, reduced inflammation as portrayed by decreased infiltration of macrophage, and downregulation MCP-1 gene expression [87]. The aqueous extract of Vigna angularis improved kidney function parameters in an experimental model of moderate chronic kidney disease [58].

In addition to medicinal plants, bee products have been used to supplement pharmacological compounds for their beneficial therapeutic activities. These effects include anti-inflammatory [88], antioxidants [89] and immunomodulatory activities [90]. A variety of preparations are produced by honeybees, such as royal jelly, propolis, bee wax, pollen grain, and bee venom [91]. A multitude number of bioactive compounds derived from honeybee products can be of value in the treatment of CKD and management of CKD complications [92,93].

Honeybee propolis is one of the significant beneficial components derived from honeybee products. Propolis contains bioactive compounds, including flavonoids such as chrysin and rutin, and phenolic compounds, such as caffeic acid and a stilbene derivative resveratrol [94]. The antioxidants characteristics of propolis are based on its content of flavonoids and phenolic compounds [95-97]. In a recent study, propolis was able to attenuate tubulointerstitial fibrosis by modulating canonical SMAD signaling pathway and JNK/ERK activation in the TGF- $\beta$ cascade in a murine model of aristolochic acids-induced nephropathy [93]. Teles et al. demonstrated that Brazilian red propolis reduced hypertension and renal morphological alterations manifested by decreased serum creatinine, proteinuria, and infiltration of macrophages in 5/6 nephrectomized rats [98]. The authors suggested that the beneficial effects of Brazilian red propolis are due to its anti-inflammatory and antioxidant 
activity. Additionally, through reducing oxidative stress and blood pressure, Indonesian propolis extract has been shown to attenuate UUO-induced renal damage [99], and Iranian propolis extract could increase the antioxidant levels and amend histopathological alterations in the DN rats model [100]. In a randomized, double-blinded, and placebo-controlled clinical trial in humans, Brazilian green propolis significantly attenuated proteinuria in diabetic and non-diabetic CKD patients [92] and reduced inflammation in patients on hemodialysis [101].

Chrysin derived from bee propolis reduced kidney fibrosis induced by the accumulation of AGEs in in vitro and in vivo studies. In the in vitro study, chrysin treatment reduced AGEs-induced deposition of collagen, induction of $\alpha$-SMA, and matrix metalloproteinases in human mesangial cells through downregulation of TGF $\beta 1$ and SMAD $2 / 3$. Moreover, these findings were confirmed in an animal model of diabetic kidney disease [102]. Furthermore, chrysin attenuated adenine-induced CKD in rats through the reduction in inflammatory cytokines, boosting antioxidant status, and improving renal histopathological alterations [103]. Caffeic acid phenethyl ester (CAPE) is one of the constituents of honeybee propolis that has been shown to protect against lithium-induced renal tubular damage and oxidative stress in a rat model by boosting the antioxidant enzymes activities (SOD, CAT, GSH-Px) in renal tissue [104]. Caffeic acid also had anti-inflammatory effects in the model of diabetic nephropathy (DN) mice by reducing renal IL-6, IL-1 $\beta$, TNF- $\alpha$, and MCP-1 levels [105]. Pinocembrin, isolated from Mexican brown propolis, has been shown in the DN rat model to be able to improve lipid profile, glomerular filtration rate, urinary protein, prevent urinary biomarker increases, oxidative stress, and glomerular basement membrane thickness [106]. Bee venom is a natural toxin produced by honeybees and possesses a multitude of beneficial health activities [107]. Bee venom treatment attenuated renal fibrosis in unilateral ureteral obstruction (UUO)-induced CKD through a reduction in the expression of inflammatory markers (TNF- $\alpha$ and IL-1 $\beta$ ), fibrotic markers (TGF- $\beta 1$ and fibronectin), and $\alpha$-SMA [108]. The mechanistic pathways targeted by some natural products against CKD are summarized in Table 1.

Table 1. Summary of clinical and experimental studies evaluating the protective effect and the possible mechanisms of different natural products against CKD. Decreased $(\downarrow)$ or increased ( $\uparrow$ ).

\begin{tabular}{|c|c|c|c|c|}
\hline Natural Products & Type of Study & Therapeutic Effect & Major Findings & References \\
\hline Phylanthus niruri & $\begin{array}{l}\text { STZ-induced diabetic } \\
\text { nephropathy } \\
\text { (in vivo) }\end{array}$ & $\begin{array}{c}\text { Antioxidant } \\
\text { Anti-inflammatory } \\
\text { Anti-apoptotic } \\
\text { Anti-fibrotic }\end{array}$ & $\begin{array}{c}\text { Kidney homogenate (TBARS } \\
\downarrow),(\text { SOD, CAT and GPx } \uparrow), \\
(\text { NF- } \mathrm{B}-\mathrm{p} 65, \text { Ikk- } \beta, \text { TNF- } \alpha, \\
\text { IL-1 } \beta \text { and IL- } 6 \downarrow) \text {, (caspase-3, } \\
\text { caspase-9, Bax } \downarrow \text { ), (TGF- } \beta 1 \text {, } \\
\text { VEGF, FGF- } 1 \downarrow),\end{array}$ & {$[61]$} \\
\hline Carya Cathayensis & $\begin{array}{l}\text { - Mouse model of UUO } \\
\text { (in vivo) } \\
\text { - TGF- } \beta 1 \text {-treated mouse } \\
\text { tubular epithelial cells } \\
\text { (mTECs) (in vitro) }\end{array}$ & Anti-fibrotic & $\begin{array}{l}\text { Collagens and } \alpha \text {-SMA } \downarrow \text { in the } \\
\text { kidneys } \\
\text { In vitro, fibrotic markers } \downarrow \text { and } \\
\text { miR-21 } \downarrow \text { in TGF- } \beta 1 \text {-treated } \\
\text { mouse tubular epithelial cells } \\
\text { (mTECs). Smad7 } \uparrow\end{array}$ & [62] \\
\hline Flos A. manihot & $\begin{array}{c}\text {-Glomerulonephritis rabbit } \\
\text { model } \\
\text { - Diabetic nephropathy } \\
\text { - Adriamycin-induced } \\
\text { nephropathy } \\
\text { - } 417 \text { patients with } \\
\text { glomerular disease stages } \\
\text { 1-2 CKD }\end{array}$ & $\begin{array}{l}\text { Renoprotective agent } \\
\text { Anti-apoptotic } \\
\text { Antioxidant }\end{array}$ & $\begin{array}{l}\text { Protein levels in urine } \downarrow \text {, } \\
\text { apoptosis of podocytes } \downarrow \text {, } \\
\text { glomerulosclerosis } \downarrow \text {, and } \\
\text { mesangial proliferation } \downarrow \\
\text { (kidneys) }\end{array}$ & [64-69] \\
\hline
\end{tabular}


Table 1. Cont.

\begin{tabular}{|c|c|c|c|c|}
\hline Natural Products & Type of Study & Therapeutic Effect & Major Findings & References \\
\hline \multirow{3}{*}{$\begin{array}{l}\text { Astragalus } \\
\text { membranaceus }\end{array}$} & $\begin{array}{l}\text { Human kidney proximal } \\
\text { tubular epithelial cells } \\
\text { (in vitro) }\end{array}$ & $\begin{array}{l}\text { Anti-apoptotic and } \\
\text { anti-inflammatory }\end{array}$ & $\begin{array}{c}\mathrm{H}_{2} \mathrm{O}_{2} \downarrow \text {, apoptosis } \downarrow, \text { NF- } \mathrm{kB} \downarrow \\
\text { TNF- } \alpha \downarrow \text { (proximal } \\
\text { epithelial cells) }\end{array}$ & [74] \\
\hline & UUO rat kidney & Anti-fibrotic & $\begin{array}{c}\text { Interstitial fibrosis } \downarrow \text { eNOS } \uparrow \text {, } \\
\text { ROS scavenging } \\
\text { (kidney tissue) }\end{array}$ & [75] \\
\hline & $\begin{array}{c}35 \text { CKD patients (Stage } 4 \text { and } \\
5 \text {, dose; } 2.5 \text { g/day) }\end{array}$ & $\begin{array}{l}\text { Delayed kidney } \\
\text { replacement }\end{array}$ & Maintain eGFR & [77] \\
\hline
\end{tabular}

1804 CKD patients with

diabetic nephropathy stage

III-IV and case study (dose

Renal protective agent Maintain serum BUN, SCr, CCr

$30 \mathrm{~g} /$ day for 1 month)

1323 CKD patients (all stages) and urine protein $\downarrow$, eGFR $\uparrow$ albumin $\uparrow$

Astragalus

Diabetic nephropathy

Anti-inflammatory

Autophagy $\uparrow, \operatorname{mTOR} \downarrow$, and PINK1/Parkin $\uparrow$

mongholicus

UUO and puromycin aminonucleoside nephrosis rat model

Anti-fibrotic

mRNA TGF- $\beta 1 \downarrow, \alpha$-SMA $\downarrow$

[81-83]

Vigna angularis

STZ-induced diabetic nephropathy (in vivo)

Antioxidant Stimulate autophagy

Plasma GSH $\uparrow$, LC3B-II $\uparrow$, mRNA HO- $1 \downarrow$, p47phox $\downarrow$, plasma MDA $\downarrow$, and mRNA MCP- $1 \downarrow$

\begin{tabular}{|c|c|c|c|c|}
\hline Propolis & $\begin{array}{l}\text { Aristolochic acids-induced } \\
\text { nephropathy (in vivo) }\end{array}$ & Anti-fibrotic & $\begin{array}{l}\text { Tubulointerstitial fibrosis } \downarrow \text {, } \\
\text { TGF- } \beta \text { /Smad pathway } \downarrow\end{array}$ & [93] \\
\hline $\begin{array}{l}\text { Brazilian red } \\
\text { propolis }\end{array}$ & $5 / 6$ nephroctomized rats & $\begin{array}{c}\text { Antioxidant } \\
\text { Anti-inflammatory }\end{array}$ & $\begin{array}{c}\text { SCr } \downarrow \text {, proteinuria } \downarrow \text { (serum } \\
\text { and urine), infiltration of } \\
\text { macrophages (kidney tissue) } \downarrow\end{array}$ & [98] \\
\hline Indonesian propolis & UUO rat model & Antioxidant & $\begin{array}{c}\text { Oxidative stress } \downarrow \text {, blood } \\
\text { pressure } \downarrow\end{array}$ & [99] \\
\hline Iranian propolis & $\begin{array}{l}\text { STZ-induced diabetic } \\
\text { nephropathy }\end{array}$ & Antioxidant & $\begin{array}{c}\text { Serum MDA } \downarrow, \operatorname{SOD} \uparrow, \text { GPx } \uparrow, \\
\text { improvement in } \\
\text { histological architecture }\end{array}$ & [100] \\
\hline $\begin{array}{l}\text { Brazilian green } \\
\text { propolis }\end{array}$ & $\begin{array}{c}148 \text { CKD patients (type } 2 \\
\text { diabetes) } \\
\text { (Dose; } 500 \mathrm{mg} / \text { day) } \\
\text { Hemodialysis patients } \\
\text { (250 mg/day, in capsules). }\end{array}$ & $\begin{array}{l}\text { Renal protective agent } \\
\text { Anti-inflammatory }\end{array}$ & $\begin{array}{l}\text { Proteinuria } \downarrow \text { (urine), } \\
\text { inflammation } \downarrow\end{array}$ & {$[92,101]$} \\
\hline \multirow[t]{2}{*}{ Bee venom } & UUO rat model & $\begin{array}{l}\text { Anti-inflammatory } \\
\text { Anti-fibrotic }\end{array}$ & $\begin{array}{l}\text { mRNA TNF- } \alpha, \text { IL- } 1 \beta \downarrow \\
\text { TGF- } \beta 1, \text { FN, } \alpha \text {-SMA } \downarrow\end{array}$ & [108] \\
\hline & \multicolumn{4}{|c|}{$\begin{array}{l}\text { STZ, streptoziticin; TBARS, thiobarbituric acid reactive substances; SOD, superoxide dismutase; CAT, catalase; } \\
\text { GPx, glutathione peroxidase; NF-kB, nuclear factor kappa B; Ikk- } \beta \text {, IkappaB kinase; TNF- } \alpha \text {, tumor necrosis factor } \\
\text { alpha; IL-1 } \beta \text {, interleukin -1 beta; IL-6, interleukin-6; Bax, BCL2-associated X protein; TGF- } \beta 1 \text {, transforming growth } \\
\text { factor-beta1; VEGF, vascular endothelial growth factor; FGF-1, fibroblast growth factor; UUO, unilateral ureteral } \\
\text { obstruction; } \alpha \text {-SMA, smooth muscle alpha-actin; miR-21, microRNA 21; eNOS, endothelial nitric oxide synthase; } \\
\text { H2O2, hydrogen peroxide; ROS, reactive oxygen species; eGFR, estimated glomerular filtration rate; BUN, } \\
\text { blood urea nitrogen; Scr, serum creatinine; CCr, creatinine clearance; mTOR, mammalian target of rapamycin; } \\
\text { PINK1/Parkin, PTEN-induced kinase } 1 \text { /Parkin; GSH, glutathione; LC3B-II, light chain 3B-II; HO-1, heme } \\
\text { oxygenase-1; p47phox, neutrophil cytosol factor 1; MDA, malondialdehyde; MCP-1, monocyte chemoattractant } \\
\text { protein-1; Smad, small mothers against decapentaplegic; FN, fibronectin. }\end{array}$} \\
\hline
\end{tabular}




\subsection{Small Bioactive Compounds against CKD}

Tiny molecular compounds derived from natural products have shown potential therapeutic effects on CKD, as indicated in previous reports [109-112]. These compounds have antioxidant [113], anti-inflammatory [114], and immunomodulatory [115] activities that are linked to their disease alleviative property. Generally, bioactive compounds exert their antioxidant activity through direct ROS scavenging and indirectly by upregulation of the body's antioxidant status. Moreover, these compounds exhibit anti-inflammatory activity through blunting inflammatory signaling cascade at the receptor and nuclear level, consequently attenuating the transcription of proinflammatory cytokines. The origin of bioactive compounds includes plants, animals, and biosynthetic sources.

\subsubsection{Berberine}

Berberine is an isoquinoline alkaloid that occurs in different plants such as Berberis vulgaris, Berberis aristata and Coptis chinensis. It possesses several pharmacological properties that include anticancer [116], antibacterial [117], anti-hyperglycemic [118], cardioprotective [119], neuroprotective [120], antiatherosclerotic [121], and anti-inflammatory activities [122].

The therapeutic and protective effects of berberine are attributed to its antioxidant and anti-inflammatory activities. The molecular basis of the aforementioned effects is due to the ability of berberine to induce the expression of Nrf2 through the activation of AMPK, P38, and PI3K/Akt signaling pathways. Consequently, boosting the antioxidant defenses manifested by the increase in SOD, GSH, and HO-1 levels [123]. Additionally, through its direct inhibitory effect on IKK- $\beta$, berberine inhibits the activation and phosphorylation of IKB- $\alpha$ and, in turn, reduces the nuclear translocation of NF- $\mathrm{BB}$ [124]. Moreover, berberine could downregulate MAPK signaling leading to direct inhibition of release of proinflammatory cytokines [125].

Berberine reduced the expression of NF- $\mathrm{KB}$ (Figure 1) in cultured mouse podocytes genetically modified to overexpress tumor necrosis factor (TNF) receptor-associated factor 5 (TRAF5), mimicking the raised levels of TRAF5 in CKD patients. Treatment by berberine reversed the reduced viability and increased apoptosis that was accompanied by the overexpression of TRAF5. The protective effect of berberine in this study is attributed to blunting inflammatory response that is associated with the upregulation of TRAF5 in CKD patients [125].

In a rat model of STZ-induced diabetic kidney disease, Zhu and colleagues reported that berberine reduced renal injury via the reduction in TLR4-dependent NF-KB-mediated inflammation [126]. In another recent study, the administration of berberine to diabetic mice attenuated the deranged lipid metabolism and mitochondrial bioenergetics associated with diabetic kidney disease. In this study, berberine induced the expression of PGC-1 $\alpha$, leading to enhanced mitochondrial function, reduced mitochondrial ROS formation, and diminished lipid deposition. Furthermore, these effects reduced injury of podocytes and increased the expression of nephrin and podocin, ameliorating diabeticinduced glomerulosclerosis and maintaining renal function [127]. Mitochondrial dynamics were also modulated by berberine in an in vitro and in vivo experiment of diabetic kidney disease [128]. Berberine treatment has been shown to reduce the expression of dynaminrelated protein 1 (Drp1) and consequently reduce the mitochondrial fission induced by palmitate treatment in cultured mouse podocytes and diabetic mice. The mitochondrial modulatory effects of berberine reduced the apoptosis of podocytes, mitochondrial ROS generation, and fragmentation. Accordingly, berberine improved the changes in podocytes structure associated with the diabetic milieu and mesangial cells along with stiffness of glomeruli [128]. Berberine therapy could improve diabetic kidney disease in patients with type 2 diabetes, as shown by the decreased level of the urinary albumin/creatine ratio (UACR) and serum cystatin C (Cys C) [129]. 


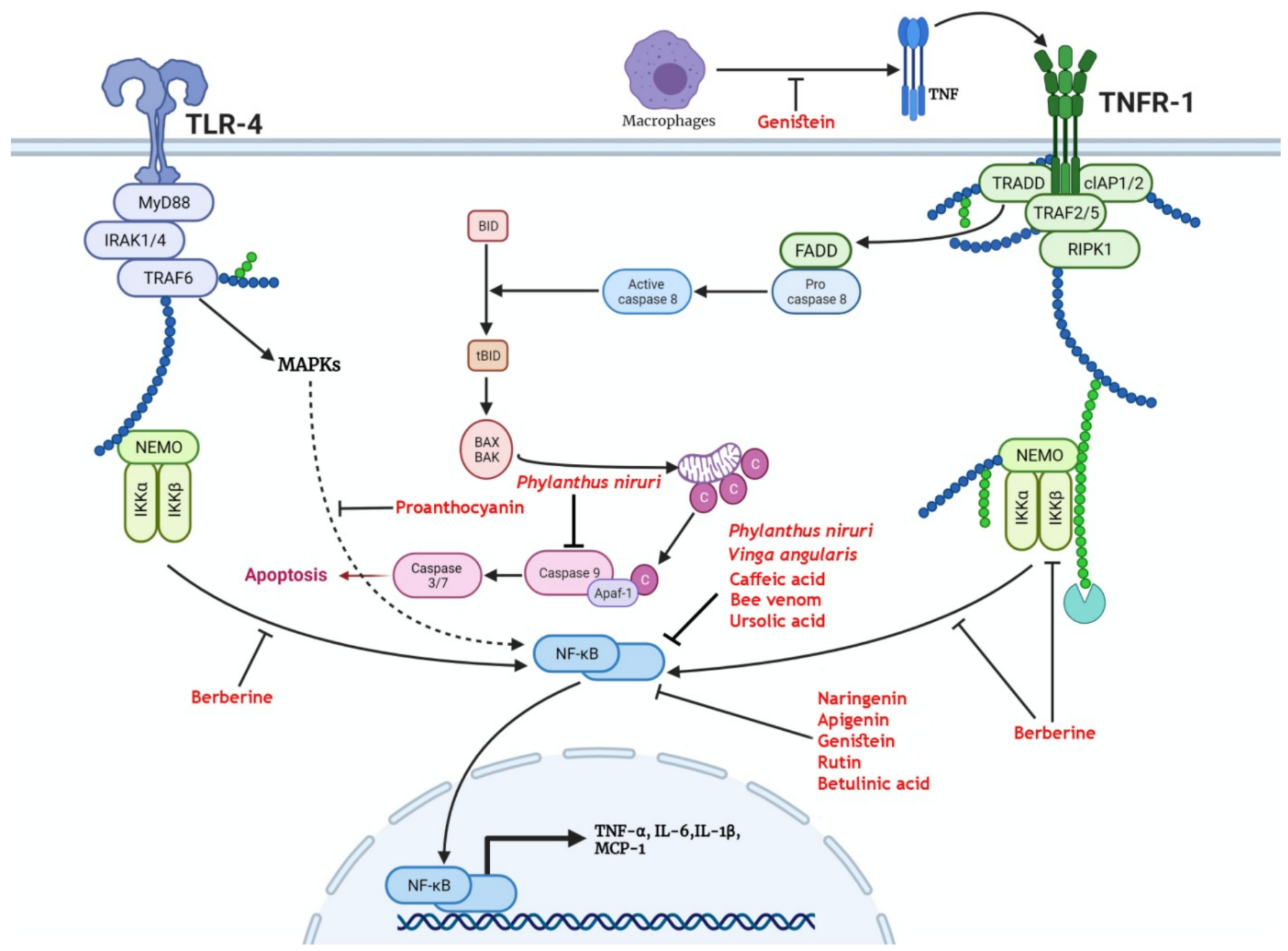

Figure 1. Medicinal plants and bioactive compounds that exert a protective effect through modulation of the nuclear factor kappa $\mathrm{B}(\mathrm{NF}-\mathrm{kB})$ pathway. Activation of either the tumor necrosis factor receptor 1 (TNFR-1) by tumor necrosis factor (TNF) or Toll-like receptor 4 (TLR-4) by pathogen-associated molecular patterns (PAMPS) leads to the recruitment of IkappaB kinase $\alpha$ (IKK $\alpha$ ) and IkappaB kinase $\beta$ (IKK $\beta$ ). These enzymes free NF- $k B$ from its sequestration in the cytosol. The tumor necrosis factor receptor type 1-associated death domain (TRADD) scaffold recruits Fas-associated death domain (FADD) that activates caspase 8, leading to the truncation of BH3-interacting domain (BID) to form tBID. Truncated BID (tBID) activates BCL2-associated X protein (BAX) and BCL2-antagonist/killer 1 (BAK) mitochondrial translocation and release of cytochrome $\mathrm{c}$ that activates effector caspases. Genistein exerts a protective effect through the inhibition of activation of TNFR-1. Berberine inhibits the recruitment of the NF- $\mathrm{kB}$ essential modulator (NEMO) complex to TNFR-1 and reduces the activation of NF-kB. Proanthocyanins inhibit mitogen-activated protein kinases (MAPKs)-mediated activation of NF-кB. Phylanthus niruri, Vinga angularis, caffeic acid, bee venom, ursolic acid, naringenin, apigenin, genistein, rutin, and betulinic acid reduce the activation and nuclear translocation of NF$\kappa \mathrm{B}$. As a consequence, the transcription and release of inflammatory cytokines and chemokines such as tumor necrosis factor- $\alpha$ (TNF- $\alpha$ ), interleukin-6 (IL-6), interleukin-1 $\beta$ (IL-1 $\beta$ ), and monocyte chemoattractant protein-1 (MCP-1) are reduced.

\subsubsection{Ursolic Acid}

Ursolic acid is a pentacyclic triterpenoid naturally present in leaves of various plants (rosemary, marjoram, lavender, thyme, and organum), fruits (apple fruit peel), flowers, and berries [130,131]. Ursolic acid in animal models and in vitro studies showed a protective effect against renal damage [132-134]. Additionally, it has been documented that ursolic 
acid has many beneficial effects, including anti-inflammatory [135], antioxidant [136], and antitumor activities [137], and prevent the progressing of chronic diseases through modulating several signaling pathways [138,139].

In the rat model of adenine-induced chronic tubular injury, administration of ursolic acid (30 mg/kg Body weight) for 28 days inhibited the activation of TGF- $\beta /$ Smad signaling and in turn reduced extracellular matrix (ECM) proteins such as fibronectin (FN) and collagen, suppressing the development and progression of renal fibrosis [140]. Additionally, in another study, ursolic acid impeded the progression of tubulointerstitial fibrosis through attenuating epithelial to mesenchymal transition in renal tubular epithelial cells along with a reduction in markers of fibrosis such as collagen 1, FN, $\alpha$-SMA, and increase in E-cadherin in a UUO mouse model of CKD. Furthermore, treatment by ursolic acid reduced the expression of $\alpha$-SMA, snail1, slug, TGF- $\beta 1$, and p-smad3 and prevented the loss of Ecadherin in an in vitro model of TGF- $\beta 1$-treated HK-2 cells [141]. Ursolic acid significantly increased protein synthesis and reduced the breakdown of proteins in vivo and in vitro models of CKD-induced muscle wasting. These effects are attributed to the ability of ursolic acid to downregulate the expression of myostatin and inflammatory cytokines such as TGF- $\beta$, IL-6, and TNF $\alpha$ [142]. In addition, ursolic acid treatment for 10 weeks alleviated diabetic kidney injury by regulating the angiotensin II type 1 receptor-associated protein (ARAP1)/angiotensin II type 1 receptor (AT1R) signaling pathway and reducing the expression of NADPH oxidase 2 (NOX2), NADPH oxidase 4 (NOX4), 8-hydroxydeoxyguanosine (8-OHdG), TGF- $\beta 1$, FN, Col IV, IL- $1 \beta$ and IL-18 at mRNA and protein level leading to inhibition of ECM accumulation, fibrosis, oxidative stress and renal inflammation [143]. The ursolic acid treatment induces the antioxidant defenses in renal tissue as exemplified by increased GSH levels and CAT, SOD, and GSH-Px enzyme activities in diabetic rats. Moreover, treatment by this bioactive compound reduced oxidative stress as shown by decreased tissue lipid peroxidation [144]. Interestingly, ursolic acid alleviated renal injury in the alloxan-induced diabetes model through the reduction in proinflammatory cytokines [145]. Uncontrolled hyperglycemia is implicated in impaired autophagy in renal cells; consequently, targeting the impaired autophagic repair machinery has the potential to amend diabetic renal injury [146]. In this regard, cultured murine podocytes exposed to high glucose levels showed reduced markers of autophagy such as LC3II and Beclin1 that were reversed upon ursolic acid treatment [147] (Figure 2). Consequently, relieving hyperglycemia-induced injury to podocytes as manifested by restoration of synaptopodin, podocin, and nephrin levels. The renal protective effects of ursolic acid were related to its inhibitory action on the PI3K/Akt/mTOR pathway via an enhancement in the expression of PTEN secondary to downregulated miR-21. The protective effect of ursolic acid was abrogated following treatment by autophagy inhibitor 3-MA further confirming its protective action through modulation of impaired autophagy [147]. 


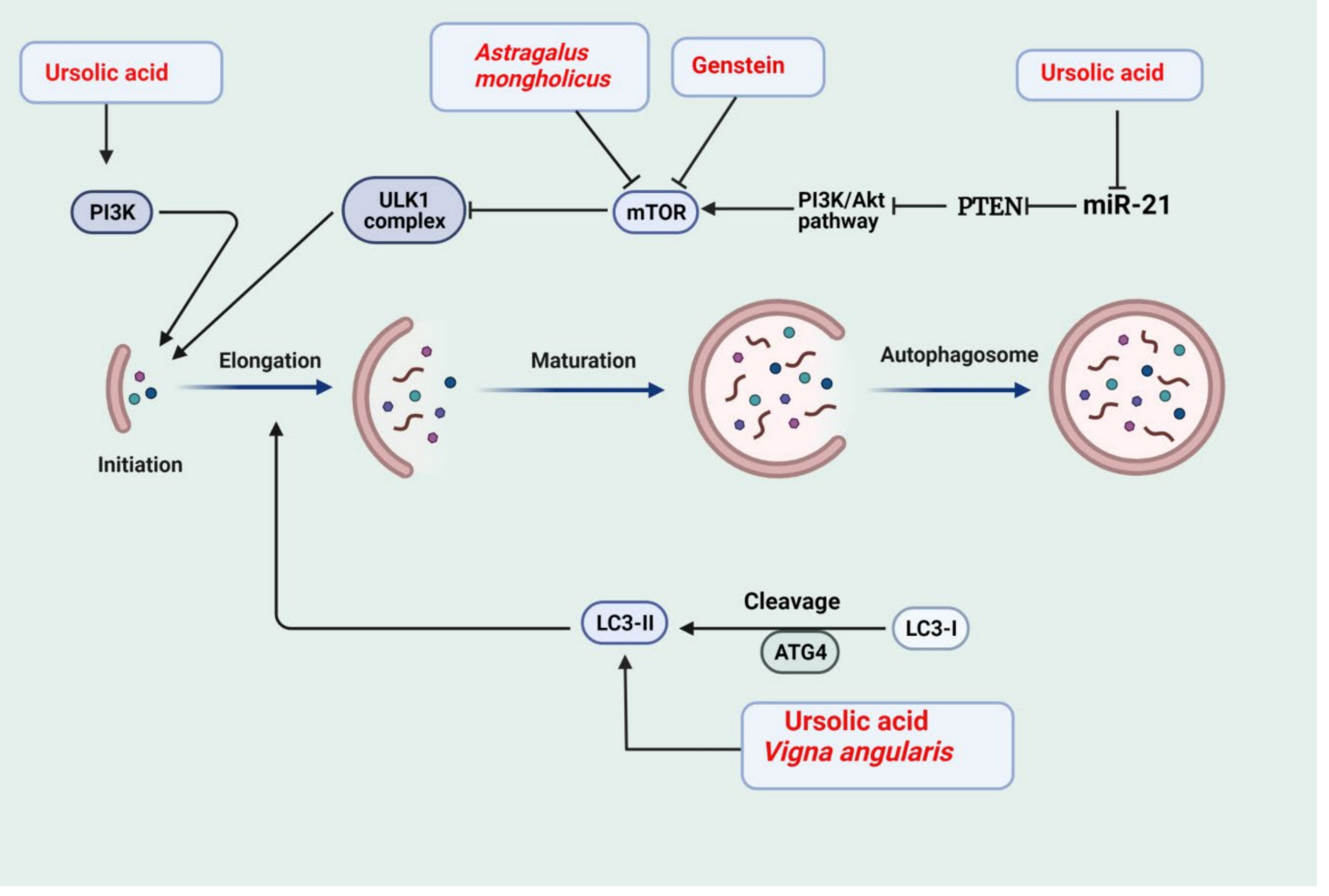

Figure 2. Medicinal plants and bioactive compounds that activate autophagy. The phosphatidylinositol-3-kinase (PI3K)/Akt and the mammalian target of rapamycin (mTOR) (PI3K/Akt/mTOR) pathway is a negative modulator of the Unc-51-like kinase 1 (ULK-1) complex. Activation of phosphoinositide 3-kinase (PI3K) and ULK-1 complex is required for initiation. Light chain 3-I (LC3-I) is cleaved to light chain3-II (LC3-II) to drive the elongation phase. This is followed by maturation to form the autophagosomes. Phosphatase and tensin homolog (PTEN) is a negative modulator of the PI3K/Akt/mTOR pathway, and microRNA-21 (miR-21) inhibits PTEN. Ursolic acid activates autophagy through inhibition of miR-21, thus allowing PTEN to inhibit $\mathrm{PI} 3 \mathrm{~K} / \mathrm{Akt} / \mathrm{mTOR}$ pathway, leading to activation of the ULK-1 complex. In addition, ursolic acid activates the PI3K complex. Therefore, ursolic acid is involved in the initiation phase of autophagy. Astragalus mongholicus and genistein inhibit mTOR, leading to activation of ULK-1. Ursolic acid and Vinga angularis drive the formation of LC3-II and the elongation phase.

\subsubsection{Naringenin}

Naringenin is one of the essential naturally occurring flavonoids found mainly in certain eatable fruits, such as tomatoes and citrus species [148]. It exhibits limited solubility in water, whereas its solubility is higher in alcohol. It is derived from the hydrolysis of naringin or narirutin [149]. The natural biosynthesis of naringenin is a multi-step process that begins with converting phenylalanine to cinnamic acid viz the action of phenylalanine ammonia-lyase. Subsequently, several enzymes catalyze multiple reactions, ultimately leading to the formation of naringenin [150].

This reaction yields a meager amount of the bioactive compound; therefore, several attempts were carried out to increase the yield of naringenin through genetic engineering. The highest yield of naringenin was obtained from genetic manipulation of Escherichia coli [151]. Following oral ingestion, naringenin is extensively degraded by the gut microbiota yielding a wide array of breakdown products, leading to reduced bioavailabil- 
ity [152]. Interestingly, the bioavailability of naringenin was found to be lower in trained athletes [153].

Naringenin revealed many pharmacological activities (for example but not limited to) on human health, which includes antidiabetic properties [154], antimetastatic [155], neuroprotection [156], suppression of proliferation of endometriosis cell lines, and increasing their apoptosis [157], as well as reducing incidence of cardiovascular diseases [158]. Generally, like most flavonoids, naringenin exerts beneficial effects owing to its antioxidant property. The antioxidant activity of naringenin is attributed to its modulatory effect on Nrf2, a major transcriptional factor for cellular antioxidant defenses [159,160]. Furthermore, naringenin possesses anti-inflammatory properties mainly through its inhibitory activity on NF- $\kappa B$ and subsequent reduction in transcription of proinflammatory cytokines $[161,162]$. Perturbations in TGF- $\beta$ signaling lead to the upregulation of pro-fibrotic transcriptional mediators that play a role in CKD progression [163].

In this context, naringenin treatment in mice with obstructive nephropathy attenuated renal fibrosis by inhibiting the expression and activation of smad3, a crucial pro-fibrotic factor, leading to a reduction in collagen I and $\alpha$-SMA in renal tissue. Similar findings were obtained from cultured normal rat kidney tubular epithelial cell line (NRK52E) subjected to recombinant human TGF- $\beta 1$ [164].

One of the etiologies of CKD is hypercholesterolemia through induction of inflammatory renal damage and oxidative stress [165]. Moreover, increased plasma cholesterol levels interfere with purinergic signaling in platelets promoting their aggregation [166]. In a rat model of high cholesterol diet-induced renal failure, naringenin treatment attenuated the hydrolysis of adenine nucleotides that is stimulated by high plasma cholesterol levels. As a consequence, several indices of oxidative stress and inflammation were improved by naringenin, including inducible NO synthase (iNOS), TNF- $\alpha$, IL-6, and NF- $k$ B. Moreover, naringenin reversed the reduction in ectonucleoside triphosphate phosphohydrolase (NTPDases) and ecto-5'-nucleotidase (CD73) activities that are associated with inflammatory signaling and enhanced platelets aggregation [167]. Naringenin has a potential renoprotective effect in diabetes, which is indicated by significant amelioration of diabetic kidney impairment. In this regard, naringenin-treated diabetic rats showed reduced renal oxidative stress, inflammation, and apoptosis compared to untreated diabetic rats. In this study, some parameters were improved by naringenin, including MDA, SOD, CAT, GSH, as well as TGF- $\beta 1$ and IL-1 [168]. Additionally, Ding and colleagues investigated the potential role of naringenin in ameliorating diabetic kidney disease through modulation of peroxisome proliferators-activated receptors (PPARs) with subsequent normalization of CYP4A expression concomitant increase in 20-hydroxyeicosatetraenoic acid (20-HETE) in diabetic mice. Similarly, the level of PPARs-CYP4A-20-HETE was recovered by naringenin in NRK-52E cells exposed to high glucose [169].

\subsubsection{Apigenin}

One of the significant flavonoids occurring in plants is flavone apigenin. It is widespread in the family Asteraceae, for example, the genera Tanacetum [170], Matricaria [171], Achillea [172], and Artemisia [173]. Apigenin is present in different forms in the family of Lamiaceae, such as the aglycone, O-glucosides, glucuronides, C-glucosides, acetylated derivatives, and O-methyl ethers [174].

Apigenin is formed from phenylalanine identical to naringenin through the phenylpropanoid pathway. Phenylalanine is converted to cinnamic acid and then to p-coumaric acid that is activated by CoA followed by condensation with three malonyl-CoA residues and aromatization to form chalcone. Chalcone isomerization yields naringenin oxidized by a flavanone synthase to apigenin [175]. Like naringenin, apigenin possesses antioxidant and anti-inflammatory activities that can benefit the prevention of the progression of chronic kidney disease. A previous review article highlighted the therapeutic potential of apigenin in several diseases with [174]. 
Mechanistically, apigenin exerts its therapeutic effects by modulating multiple functions such as induction of cell cycle arrest and apoptosis in cancer cells [176]. Apigenin modulates the cell cycle by altering the expression of cyclin-dependent kinases (CDKs). Moreover, apigenin induces apoptotic cell death through mitochondrial (intrinsic) and non-mitochondrial (extrinsic) pathways. In the intrinsic pathway, apigenin acts directly on the mitochondrial membrane, leading to the depolarization of the mitochondrial membrane potential and causing an increase in the mitochondrial permeability transition, ultimately stimulating the release of cytochrome $\mathrm{C}$ and subsequently activating the cytoplasmic executioner caspases [177]. Apart from its mitochondrial cell death-promoting activity, it upregulates the expression of death receptor 5 (DR5), inducing tumor necrosis factorrelated apoptosis-inducing ligand (TRAIL)-mediated caspase eight activations [178]. The anti-inflammatory activity of apigenin is related to its modulation of several pathways such as PI3K/Akt, p38/MAPK, stabilization of IKB leading to a reduction in the nuclear translocation of NF- $\mathrm{kB}$, and inhibition of COX-2 [179]. Apigenin promotes the cellular antioxidant capabilities by enhancing the expression of antioxidant enzymes (SOD, CAT, and GSH-synthase) and induction of Nrf-2 nuclear translocation [180,181].

Previous studies have shown the renoprotective effect of apigenin through the attenuation of renal fibrosis via activation of AMPK leading to the inactivation of the TGF$\beta 1 / \operatorname{Smad} 2 / 3$ signaling pathway $[182,183]$. Uremia associated with the build-up of toxic compounds secondary to renal dysfunction is a major contributor to endothelial dysfunction and cardiovascular disease. In an in vitro study, cultured human endothelial cells recovered from umbilical veins were subjected to uremic sera isolated from ESRD patients on peritoneal dialysis. Concurrent treatment by apigenin attenuated the dysfunction associated with the exposure of endothelial cells to uremic sera. The authors concluded that apigenin exerted its beneficial effect by reducing oxidative stress and inhibiting p38/MAPK activation [184]. The NAD+-dependent Sirt3 is critical for the proper functioning of mitochondrial respiration and redox state in the high energy demanding renal tubular epithelial cells [185]. Depletion of NAD+ leads to inactivation of mitochondrial Sirt3 compromising mitochondrial function and leading to excessive ROS generation [186]. In a diabetic rat model, apigenin alleviated mitochondrial-induced oxidative stress due to reduced Sirt3 activity through inhibition of CD38-mediated consumption of NAD+ in renal tubular cells [187]. In another study, Li et al. demonstrated the ability of apigenin nanoparticles to reduce renal damage associated with diabetic kidney disease through activation of Nrf2/HO-1 and inhibition of the NF-kB signaling pathway [188] (Figure 3).

\subsubsection{Genistein}

Genistein is a typical, naturally occurring soy isoflavone isolated from Genista tinctoria for the first time [189]. Due to the similarities in structure to estradiol, genistein possesses estrogen-like functions [190]. Genistein has rapid metabolism in the liver and the intestine after $30 \mathrm{~min}$ of administration [191]. As reported in a previous review, genistein has multiple significant impacts in the treatment of metabolic diseases such as obesity, diabetes, and atherosclerosis, as well as anti-proliferative activity against cancer [192]. It also can control, prevent and treat various body disorders by modulating specific molecular pathways [193-195]. 


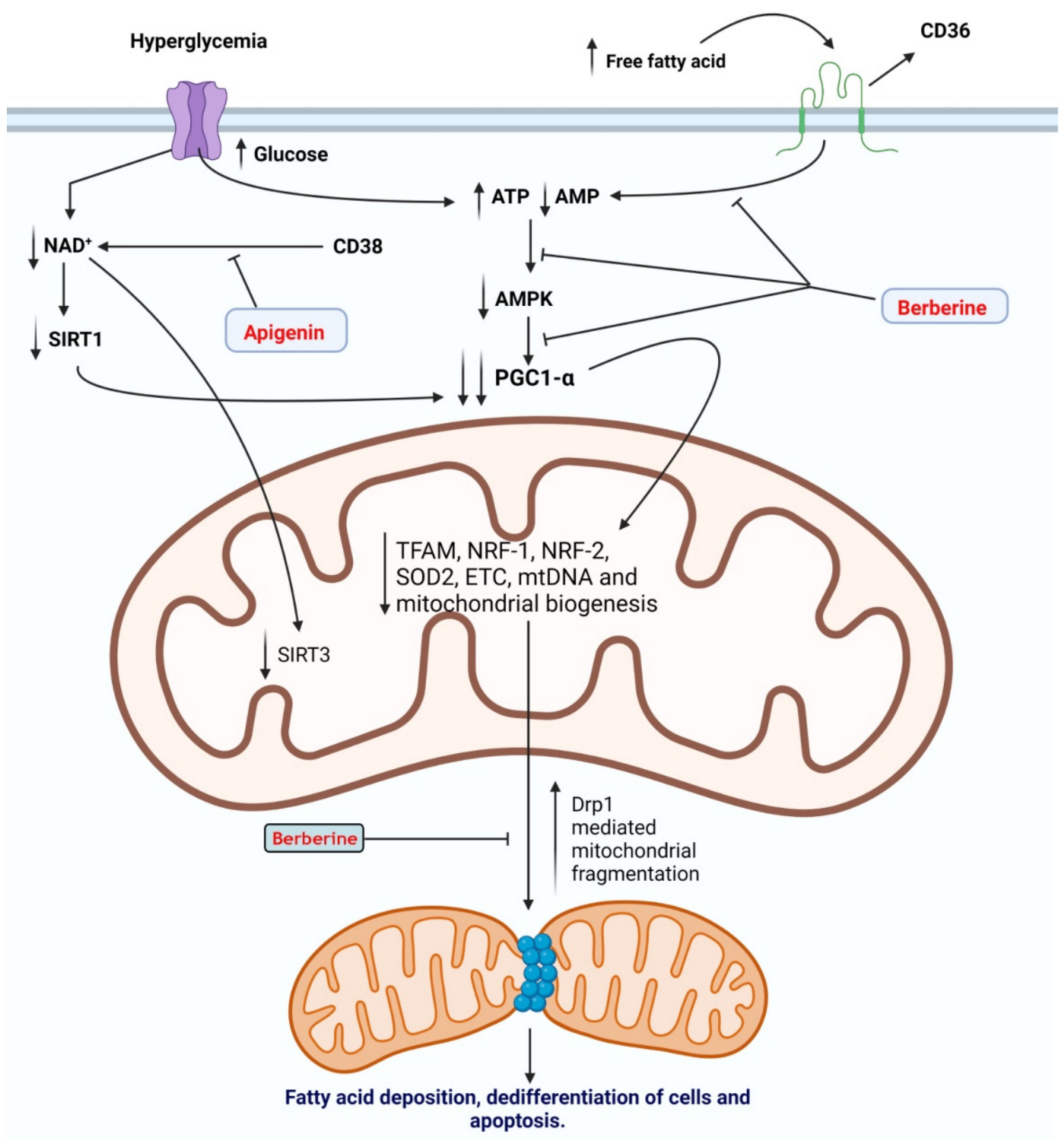

Figure 3. Medicinal plants and bioactive compounds that increase mitochondrial bioenergetics and prevent mitochondrial dysfunction. Hyperglycemia is accompanied by an increase in oxidative phosphorylation, leading to an increase in the adenosine triphosphate (ATP) to adenosine monophosphate (AMP) ratio and a reduction in nicotinamide adenine dinucleotide $\left(\mathrm{NAD}^{+}\right)$: nicotinamide adenine dinucleotide hydrogen $\left(\mathrm{NADH}^{+}\right)$ratio. Reduction in AMP and NAD leads to inactivation of activated protein kinase (AMPK) and sirtuin-1 (SIRT1), respectively. This, in turn, leads to the inhibition of peroxisome proliferator-activated receptor-gamma coactivator $-1 \alpha$ (PGC1- $\alpha$ ), the master regulator of mitochondrial biogenesisSimilarly, an increase in free fatty acids (FFA) levels activates a cluster of differentiation 36 (CD36), leading to the inactivation of AMPK and PGC1- $\alpha$. Reduced mitochondrial biogenesis leads to recruitment of cytosolic Drp1 to the outer mitochondrial membrane and an increase in mitochondrial fission. Consequently, mitochondrial fragmentation leads to a reduction in fatty acid oxidation and accumulation of FFA, leading to dedifferentiation of renal cells and apoptosis. Berberine inhibits the inactivation of AMPK and the recruitment of dynamin-related protein1 (Drp1) to the mitochondrial membrane. Thus, maintaining mitochondrial biogenesis and bioenergetics and preventing mitochondrial dysfunction that results from hyperglycemia and the increase in levels of FFA. Apigenin inhibits CD38-mediated consumption of NAD, thus preventing the inactivation of sirtuin-1 (SIRT1) and sirtuin-3 (SIRT3). 
Among these pathophysiological pathways, genistein has been shown to be capable of preventing diabetic osteoporosis through activation of $\beta$-catenin, runt-related transcription factor 2 (Runx-2), inhibition of receptor activator of nuclear factor $\kappa B$ ligand (RANKL) and peroxisome proliferator-activated receptor- $\gamma$ (PPAR- $\gamma$ ) signaling pathways [196]. One of the possible mechanisms through which genistein induces apoptosis and cell cycle arrest in cancerous cells is by the inhibition of NF- $\mathrm{KB}$ and modulating the levels of antiapoptotic protein Bcl-2 and proapoptotic protein (Bax), as well as modulating caspase-3 and p38/MAPK signaling pathways $[197,198]$. In addition, genistein was reported to improve glycated hemoglobin, blood glucose levels, triglyceride and decrease oxidative stress marker (MDA) in postmenopausal women with type 2 diabetes mellitus [199]. A substantial number of studies have reported the anti-inflammatory properties of genistein through inhibition of COX-2 and downregulation of proinflammatory markers such as TNF- $\alpha$, IL-1 $\beta$, IL-6, and NF-kB [200-202].

Concerning the anti-fibrotic effect of genistein, a study in a rat diabetic model revealed that genistein treatment attenuated renal fibrosis as shown by lower levels of TGF- $\beta 1$, p-Smad3, and collagen IV compared to diabetic untreated rats [203]. Similar observations were drawn from an early study involving cultured rat mesangial cells exposed to high glucose [204]. It has been reported that renal autophagic repair is impaired in CKD [205]. This was confirmed in an in vitro study of cultured murine podocytes treated by high glucose that showed unsustained autophagic repair compared to cells treated by genistein. The authors stipulated that genistein enhances autophagy through inhibition of mTOR signaling. Additionally, the autophagic repair was sustained in the presence of chloroquine and siRNA targeting the protein MyD88 [206]. The antioxidant and anti-inflammatory properties of genistein were shown to protect against diabetic renal damage in a mouse model of alloxan-induced diabetes. The markers of inflammation, including Cox-2, MCP-1, $\mathrm{TNF}-\alpha$, and NF- $\mathrm{B}$, were reduced in the genistein-treated group compared to untreated diabetic mice. Similarly, genistein reduced the markers of oxidative stress (MDA) and increased the cellular antioxidant defenses (Nrf2, GPx, SOD, and HO-1) [207].

In an experimental study involving healthy subjects and hemodialysis patients, withdrawn whole blood and isolated mononuclear cells pre-incubated with genistein showed a lower activatory tendency and low levels of TNF- $\alpha$ secretion in whole blood and monocytes of hemodialysis patients exposed to LPS. However, no significant alteration in the level of IL-6 and IL-10 was found in the treated and untreated healthy and hemodialysis patient groups. The authors concluded that the anti-inflammatory activity of genistein was due to its inhibitory activity on TNF- $\alpha$ release from monocytes in response to proinflammatory stimuli [208].

\subsubsection{Rutin}

Rutin is a glycoside of the flavonoid quercetin that can be naturally present in many plants, including citrus fruits, buckwheat, tobacco, tea, and passion flower $[209,210]$. Rutin nomenclature is derived from the plant Ruta graveolens and also can be called rutoside, quercetin-3-O-rutinoside, rutinum, sophorin, and vitamin P [211]. Rutin's chemical structure consists of flavonolic aglycone quercetin plus rutinose disaccharide.

Pharmacological reports have proposed that rutin has antioxidant and anti-inflammatory effects, and therefore might be considered for the treatment and management of CKD. The antioxidant properties of rutin are owing to its ability to suppress the oxidation process, scavenge released free radicals and enhance antioxidant enzyme activities [212]. On this point, rutin treatment has shown strong DPPH radical scavenging activity and effective inhibition of lipid peroxidation [213]. Additionally, the antioxidant activity of rutin is based on promoting the release of antioxidant enzymes induced by Nrf2 upregulation (Figure 4) [214,215]. Rutin had anti-inflammatory properties primarily through inhibiting NF- $\kappa \mathrm{B}$ pathway activation and subsequently reducing the release of proinflammatory cytokines such as TNF- $\alpha$, IL-1 $\beta$, and IL-6. In this respect, rutin has been shown to have 
anti-inflammatory effects in a mouse model of LPS-induced mastitis through inhibition of the NF- $\mathrm{KB}$ signaling pathway and attenuation of endoplasmic reticulum (ER) stress [216].

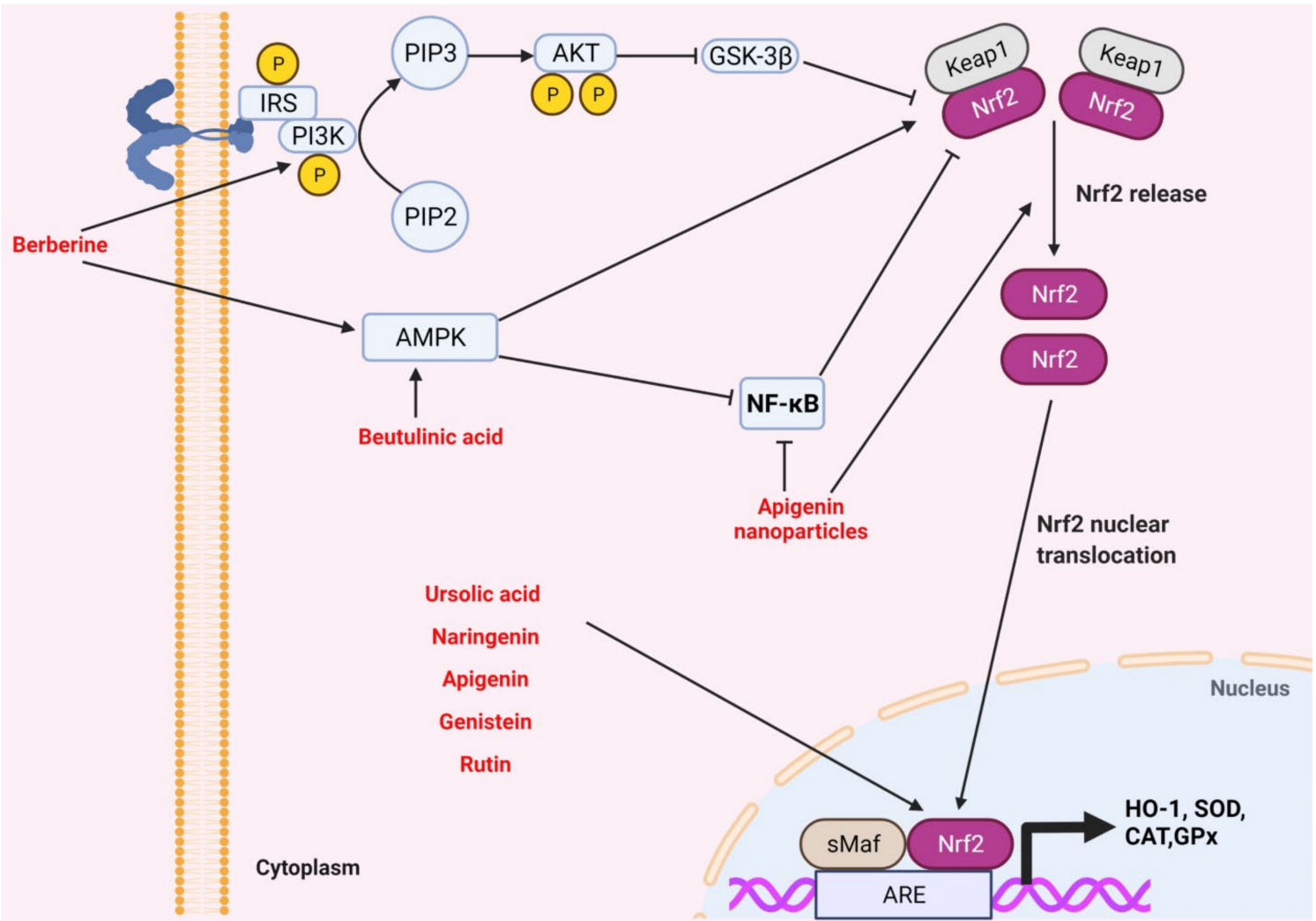

Figure 4. Medicinal plants and bioactive compounds that activate the Kelch-like ECH-associated protein 1/nuclear factor erythroid 2-related factor 2/antioxidant response element (Keap1/Nrf2/ARE pathway). Activation of the insulin receptor recruits PI3K that converts phosphatidylinositol 4,5bisphosphate (PIP2) to phosphatidylinositol 3,4,5-triphosphate (PIP3). PIP3 activates Akt, which in turn inhibits glycogen synthase kinase $3 \beta$ (GSK-3 $\beta$ ), relieving its inhibitory action on cytosolic Nrf2. Activation of AMPK releases cytosolic Nrf2 from Keap1 in a direct and an indirect manner. The nuclear translocation of cytosolic Nrf2 leads to activation of the antioxidant response element and transcription of antioxidant enzymes such as heme oxygenase-1 (HO-1), super oxide dismutase (SOD), catalase (CAT), and glutathione peroxidase (GPx). Berberine directly activates PIP3, leading to AKT-mediated activation of cytosolic Nrf2 through inhibition of GSK-3 $\beta$. In addition, berberine and betulinic acid activate AMPK, leading to the release of cytosolic Nrf2. Apigenin nanoparticles inhibit NF- $\mathrm{kB}$, thus allowing for the release of Nrf2. Ursolic acid, naringenin, apigenin, genistein, and rutin increase the nuclear level of Nrf2 and its transcriptional activity, leading to an increase in the expression of antioxidant enzymes.

Animal model results showed that rutin treatment (100 mg/kg/day) for eight weeks improved renal structure (tubulointerstitial fibrosis) and function (urea, creatinine, uric acid, and proteinuria) in adenine-induced CKD by reducing the expression of biomarkers of oxidative stress (HO-1) and inflammation phospholipase A2 (PLA-2) [217]. In another study, rats that underwent 5/6 nephrectomy showed that rutin administration for 20 weeks decreased renal fibrosis and reduced proteinuria, the authors of the study related these effects of rutin to its antioxidant properties and the suppression of the TGF $\beta 1-S m a d$ signaling pathway [218]. Wang and colleagues made similar observations; they reported that rutin treatment attenuated interstitial renal fibrosis in UUO rats, which was shown by inhibiting extracellular matrix accumulation through reducing expression of type I/III collagen and fibronectin along with preventing the epithelial-mesenchymal transition in renal tubular cells by decreasing $\alpha$-SMA expression and reserving E-cadherin expression. 
The authors correlated the renoprotective role of rutin with its anti-inflammatory effects and TGF- $\beta 1 /$ Smad3 signaling pathway inhibition [219]. The renoprotective effect of rutin on high cholesterol diet (HCD)-mediated renal injury has also been observed when co-treated with ascorbic acid through inhibiting oxidative stress and boosting cellular antioxidant defenses [220].

It has been reported that rutin therapy markedly prevented hyperglycemia-induced endothelial barrier dysfunction in endothelial cells of human renal glomeruli exposed to hyperglycemia by inhibiting the signaling pathway of ras homolog gene family, member A/ Rho-associated protein kinase (RhoA/ROCK) by the activation of Nrf2 [221].

A study in a model of alloxan-induced diabetic kidney disease (DKD) in rats revealed that rutin in combination with ramipril alleviated renal damage through a reduction in oxidative stress and renal fibrosis; the authors reported reduced TGF- $\beta 1$ and increased podocin levels in rats treated by the combination in comparison to untreated rats and rats treated with ramipril alone. Histopathological examination demonstrated improved tubulointerstitial architecture in rats treated by rutin in combination with ramipril. Moreover, the addition of rutin further attenuated endoplasmic reticulum stress in renal cells, as shown by reduced levels of unfolded protein response markers GRP78 and CHOP [222]. Another study in alloxan-treated rats showed that rutin possesses renoprotective activity as shown by its ability to reduce the biochemical markers of renal injury such as serum creatinine, blood urea nitrogen, and ketone bodies. Furthermore, rutin-treated rats had lower metabolic acidosis associated with diabetic kidney injury compared to untreated rats, as shown by reduction in gene expression of aquaporin-2 (AQP2), aquaporin-3 (AQP3), and the type 2 vasopressin receptor (V2R). The protective activity of rutin extended to the reduction in serum triglycerides and cholesterol and improvement in histopathological study results, particularly fibrosis and diabetic ketoacidosis [223].

Renal fibrosis and hyperglycemia-induced glycosylation of proteins and fats are associated with the progression of DKD. In this regard, the administration of rutin attenuated renal fibrosis by reducing the expression of collagen IV, laminin, TGF- $\beta 1$, p-Smad $2 / 3$, and connective tissue growth factor (CTGF) in a rat model of STZ-induced DKD. Moreover, rutin reduced the fasting blood glucose, serum creatinine, BUN and urinary protein level in diabetic rats compared to untreated rats. In addition, oxidative stress and AGEs were reduced in the rutin-treated group, whereas the anti-fibrotic protein p-smad 7 was increased. Electron microscopy examination revealed that rutin reduced mesangial cell expansion seen in the STZ-treated group and prevented reducing the thickness of the glomerular basement membrane [224].

\subsubsection{Proanthocyanin}

Proanthocyanidins are naturally polyphenolic compounds in the majority of plants with very potent antioxidants properties. Chemically, they are produced from flavan3-ols polymerization resulting in high molecular weight compounds called condensed tannins. They are considered oligomers or polymers of catechins or flavanols, joined by carbon-carbon bonds, with a complex chemical structure [225].

The predominant important properties of proanthocyanidins are their antioxidant activity by inhibiting the formation of free radicals in the body [226]. Scavenging these free radicals or preventing their production has beneficial effects and is considered the main strategy in treating various diseases. Proanthocyanidins also exhibit anti-inflammatory activity by inhibiting the activation of NF- $\kappa B$ signaling cascade via MAP kinases and consequently reducing the release of proinflammatory cytokines such as IL- $1 \beta$, IL-6, and IL8 [227]. Additionally, proanthocyanidins have been reported to have several biological functions, including antidiabetic, anti-atherosclerotic, and cardioprotective activities [228-230], as well as cardiovascular diseases control and treatment [231].

In an experimental animal model of mice undergoing unilateral I/ $\mathrm{R}$, administration of grape seed proanthocyanidins extract (GSPE) attenuated chronic renal fibrosis and reduced inflammation. In addition, GSPE improved parameters of renal function such as BUN and 
creatinine and reduced pathological alterations and inflammation. The authors attributed the renoprotective effect of GSPE to the inhibition of high-mobility group box 1 (HMGB1) production [232]. In another study, GSPE administration $(125,250$, or $500 \mathrm{mg} / \mathrm{kg} /$ day orally) for eight days alleviated chronic renal fibrosis and inflammation in UUO mice by inhibiting the complement component 3 (C3) produced by macrophages. This finding was supported in an in vitro experiment of cultured primary renal tubular epithelial cells (PTEC) in which treatment with GSPE inhibited C3 and decreased HMGB1 through suppressing the HMGB1/TLR4/p65/TGF- $\beta 1$ signaling pathway. Furthermore, GSPE inhibited myofibroblast activation through TGF- $\beta 1 / \mathrm{Smad} 2 / 3$ signaling pathways in normal rat kidney fibroblast (NRK-49F) cells [233].

Many studies have been performed to examine the beneficial effect of treatment with GSPE on the prevention of diabetic kidney disease progression. In this respect, it has been reported that treatment with GSPE (500 mg/ $\mathrm{kg} /$ day) for 24 weeks attenuated diabetic nephropathy by suppressing AGEs/RAGE axis and downregulation in the expression of connective tissue growth factor (CTGF) at mRNA and protein levels [234]. In another study, STZ-induced diabetic rat model, co-treatment of proanthocyanidin with thymoquinone exerted renoprotective effect as shown by a decrease in the elevated levels of urea, creatinine, nitric oxide, MDA, and IL-6 in addition to an increase in antioxidant enzymes (GSH and SOD) compared with untreated diabetic rats [235]. Similarly, GSPE treatment slowed the progression of DKD through the activation of the Nrf2 signaling pathway [236]. Additionally, in a rat model of nephropathy associated with type 2 diabetes induced by STZ and a high-fat diet, Boa et al. showed that GSPE treatment for 16 weeks could alleviate renal injury by inhibiting inflammation and boosting antioxidant activity [237]. GSPE also protected the kidneys in STZ-induced diabetic rats by attenuating programmed cell death induced by endoplasmic reticulum stress via reducing the expression of glucose-regulated protein levels 78 (GRP78), p-ERK, and caspase 12 levels [238].

In a recent review study, the utility of food containing proanthocyanidins for middleaged and older women was documented. Proanthocyanidins have been documented to contribute to preventing a wide range of diseases, as well as improving menopausal disorders, kidney function, and skin injury [239]. Furthermore, intake of proanthocyanidins has been reported to enhance renal function in women over 75 years of age [240]. As endothelial dysfunction is associated with human diabetic nephropathy, a randomized, double-blind, placebo-controlled study has revealed that GSPE intake for 12 weeks maintains vascular elasticity and normal blood pressure in volunteers with prehypertension [241].

\subsubsection{Betulinic Acid}

Betulinic acid is a pentacyclic lupane-type triterpenoid that occurs naturally in many plants, particularly birch trees [242]. Previous reports have shown that betulinic acid possesses comprehensive biological activities including anti-viral [243], antioxidant [244], hepatoprotective [245], renoprotective [246] and anti-inflammatory [247]. Furthermore, betulinic acid has anti-proliferative and anti-apoptotic properties in many cancer cell types $[248,249]$. In a recently published review, the molecular mechanisms underlying the antitumor activity of betulinic acid were summarized [250]. Two main steps are involved in the betulinic acid biosynthesis process: lupeol synthesis by 2.3-oxidosqualene cycling and subsequently oxidation by cytochrome P450 enzymes in the C28 position (CYP) [251].

The renoprotective effect of betulinic acid has been demonstrated in previous studies [252-254]. The antioxidant and anti-inflammatory properties of betulinic acid may be the leading cause of this effect. In particular, betulinic acid treatment has been shown to attenuate renal fibrosis in the CKD rat model by inhibiting levels of pro-fibrotic protein such as TGF- $\beta$, connective tissue growth factor (CTGF), fibronectin, collagen type I, and hydroxyproline, as well as enhancing renal structure and function (Figure 5) [255]. In addition, betulinic acid treatment suppressed diabetic renal fibrosis in STZ-induced diabetic rat kidneys and high glucose-treated glomerular mesangial cells by reducing the breakdown of $\mathrm{I} \kappa \mathrm{B} \alpha$ and the activity of NF- $\kappa \mathrm{B}$ and subsequently downregulation of fibronectin expres- 
sion [256]. Betulinic acid therapy inhibited oxidative stress (MDA) and proinflammatory (IL-6, IL-1 $\beta$, TNF- $\alpha$ ) cytokines and improved cellular antioxidant enzymes (SOD and CAT) in STZ-induced DKD, the authors of this study related the protective role of betulinic acid to its effect on the pathway of AMPK/NF-kB/Nrf2 [257]. Similarly, but in another experimental model of membranous nephropathy, betulinic acid treatment enhanced the antioxidant status and relieved kidney inflammation through modulation in the expression of NF- $k$ B, iNOS, TNF- $\alpha$, Nrf2, HO-1, and NQO1 at both mRNA and protein levels [258]. Despite these exciting results, no clinical trial demonstrating the potential protective role of betulinic acid in the treatment of CKD patients has been conducted. Small bioactive compounds with anti-inflammatory and antioxidants properties against CKD are summarized in Table 2.

Table 2. Overview of studies investigating the protective effect and the possible mechanistic pathways of small bioactive compounds against CKD. Decreased $(\downarrow)$ or increased ( $\uparrow$ ).

\begin{tabular}{|c|c|c|c|c|}
\hline $\begin{array}{l}\text { Small Bioactive } \\
\text { Compounds }\end{array}$ & Type of Study & Therapeutic Effect & Major Findings & References \\
\hline \multirow{2}{*}{ Chrysin } & $\begin{array}{l}\text { Human mesangial cells } \\
\text { (in vitro) } \\
\text { Diabetic kidney disease } \\
\text { (in vivo) }\end{array}$ & Anti-fibrotic & TGF $\beta 1$ and SMAD $2 / 3 \downarrow$ & [102] \\
\hline & $\begin{array}{l}\text { Adenine-induced CKD } \\
\text { (in vivo) }\end{array}$ & $\begin{array}{l}\text { Anti-inflammatory } \\
\text { Antioxidant }\end{array}$ & $\begin{array}{c}\text { Plasma TNF- } \alpha \downarrow, \\
\text { SOD, CAT, GSH, TAC } \uparrow \\
\text { (renal homogenate) }\end{array}$ & [103] \\
\hline $\begin{array}{l}\text { Caffeic acid } \\
\text { phenethyl ester } \\
\text { (CAPE) }\end{array}$ & $\begin{array}{l}\text { Lithium-induced renal toxicity } \\
\text { (in vivo) }\end{array}$ & Antioxidant & $\begin{array}{c}\text { Oxidative stress } \downarrow \text {, } \\
\text { Antioxidant enzymes } \uparrow\end{array}$ & [105] \\
\hline Caffeic acid & $\begin{array}{l}\text { STZ-induced diabetic } \\
\text { nephropathy (in vivo) }\end{array}$ & Anti-inflammatory & $\begin{array}{c}\text { IL-6, IL-1 } \beta, \text { TNF- } \alpha \text {, and MCP-1 } \\
\downarrow\end{array}$ & [106] \\
\hline Pinocembrin & $\begin{array}{l}\text { STZ-induced diabetic } \\
\text { nephropathy (in vivo) }\end{array}$ & Antioxidant & $\begin{array}{l}\text { Oxidative stress and } \\
\text { dyslipidemia } \downarrow\end{array}$ & [107] \\
\hline \multirow{4}{*}{ Berberine } & $\begin{array}{l}\text { - Cultured mouse podocytes } \\
\text { (in vitro) }\end{array}$ & Anti-inflammatory & $N F-\kappa B \downarrow$ & [125] \\
\hline & $\begin{array}{l}\text { - STZ-induced diabetic } \\
\text { nephropathy (in vivo) }\end{array}$ & Anti-inflammatory & TLR4, NF- $\mathrm{B} \downarrow \downarrow$ & [126] \\
\hline & $\begin{array}{l}\text { - Diabetic nephropathy } \\
\text { (in vitro) }\end{array}$ & $\begin{array}{l}\text { Prevent mitochondrial } \\
\text { dysfunction }\end{array}$ & $\begin{array}{c}\text { PGC-1 } \alpha \uparrow, \text { mitochondrial ROS } \\
\downarrow\end{array}$ & [127] \\
\hline & $\begin{array}{l}\text { - } 114 \text { diabetic patients (type } 2 \\
\text { diabetes) (0.4 g, } 3 \text { times a day) }\end{array}$ & Antioxidant & $\begin{array}{c}\text { Urinary albumin/creatine } \\
\text { ratio (UACR) } \downarrow \\
\text { and serum cystatin C (Cys C) } \downarrow\end{array}$ & [129] \\
\hline \multirow[t]{5}{*}{ Ursolic acid } & $\begin{array}{l}\text { - Adenine-induced kidney } \\
\text { injury (in vivo) }\end{array}$ & Anti-fibrotic & $\begin{array}{c}\text { TGF- } \beta / \text { Smad } \downarrow, \text { FN and } \\
\text { collagen } \downarrow\end{array}$ & [140] \\
\hline & $\begin{array}{l}\text { - UUO mouse model (in vivo) } \\
\text { and TGF- } \beta 1 \text {-treated HK- } 2 \text { cells } \\
\text { (in vitro) }\end{array}$ & Anti-fibrotic & $\begin{array}{l}\text { Collagen } 1, \mathrm{FN}, \alpha \text {-SMA, snail1, } \\
\text { slug, TGF- } \beta 1 \text {, and p-smad } 3 \downarrow\end{array}$ & [141] \\
\hline & $\begin{array}{l}\text { - CKD nephroctomized mouse } \\
\text { model (in vivo) }\end{array}$ & Anti-inflammatory & TGF- $\beta$, IL- 6 , and TNF $\alpha \downarrow$ & [142] \\
\hline & Diabetic nephropathy (in vivo) & $\begin{array}{l}\text { Anti-fibrotic } \\
\text { Anti-inflammatory } \\
\text { Antioxidant }\end{array}$ & $\begin{array}{c}\text { ARAP1/AT1R } \downarrow \text {, renal } \\
\text { inflammation, fibrosis, and } \\
\text { oxidative stress } \downarrow\end{array}$ & [143-145] \\
\hline & $\begin{array}{l}\text { Cultured murine podocytes } \\
\text { (in vitro) }\end{array}$ & Activate autophagy & LC3II and Beclin1 $\uparrow$ & [147] \\
\hline
\end{tabular}


Table 2. Cont.

\begin{tabular}{|c|c|c|c|c|}
\hline $\begin{array}{l}\text { Small Bioactive } \\
\text { Compounds }\end{array}$ & Type of Study & Therapeutic Effect & Major Findings & References \\
\hline \multirow{4}{*}{ Naringenin } & $\begin{array}{l}\text { - Obstructive nephropathy } \\
\text { mice model and cell line } \\
\text { (NRK52E) }\end{array}$ & Anti-fibrotic & $\begin{array}{c}\text { Smad3 } \downarrow \text {, collagen I, } \alpha \text {-SMA } \downarrow \\
\text { (renal tissue) }\end{array}$ & [164] \\
\hline & $\begin{array}{l}\text { - High cholesterol diet } \\
\text { rat model }\end{array}$ & $\begin{array}{c}\text { Antioxidant } \\
\text { Anti-inflammatory }\end{array}$ & $\begin{array}{c}\text { iNOS, TNF- } \alpha \text {, IL-6, and } \\
\text { NF- } \mathrm{B} \downarrow \\
\text { (renal tissue) }\end{array}$ & [167] \\
\hline & - Diabetic rat model & $\begin{array}{c}\text { Antioxidant } \\
\text { Anti-fibrotic } \\
\text { Anti-inflammatory }\end{array}$ & $\begin{array}{c}\text { MDA } \downarrow,(\text { SOD }, \text { CAT, GSH } \uparrow), \\
\text { TGF- } \beta 1 \text { and IL- } 1 \downarrow \\
\text { (renal tissue) }\end{array}$ & [168] \\
\hline & $\begin{array}{l}\text { Diabetic mice model and } \\
\text { NRK-52E cells }\end{array}$ & Renoprotective & $\begin{array}{c}\text { PPARs-CYP4A-20-HETE } \\
\text { pathway } \uparrow\end{array}$ & [169] \\
\hline \multirow[t]{2}{*}{ Apigenin } & $\begin{array}{l}\text { Human endothelial cells } \\
\text { (in vitro) }\end{array}$ & Antioxidant & $\begin{array}{c}\text { Oxidative stress } \downarrow \text {, p38/MAPK } \\
\text { pathway } \downarrow\end{array}$ & [184] \\
\hline & Diabetic rat model & $\begin{array}{c}\text { Activation of } \\
\text { autophagy } \\
\text { Anti-inflammatory }\end{array}$ & $\begin{array}{c}\text { Mitochondrial dysfunction } \downarrow \text {, } \\
\text { oxidative stress } \downarrow \text {, Sirt } 3 \downarrow \text {, } \\
\text { CD38 } \downarrow \\
\text { Nrf2/HO- } 1 \uparrow, \text { NF-kB } \downarrow\end{array}$ & {$[187,188]$} \\
\hline \multirow{4}{*}{ Genistein } & $\begin{array}{l}\text { Diabetic rat model and rat } \\
\text { mesangial cells exposed to } \\
\text { high glucose }\end{array}$ & Anti-fibrotic & $\begin{array}{c}\text { TGF- } \beta 1, \text { p-Smad3, collagen } \\
\text { IV } \downarrow \\
\text { (renal tissue) }\end{array}$ & {$[203,204]$} \\
\hline & $\begin{array}{l}\text { Cultured murine podocytes } \\
\text { exposed to high glucose }\end{array}$ & $\begin{array}{l}\text { Activation of } \\
\text { autophagy }\end{array}$ & $\begin{array}{c}\text { Autophagy } \uparrow, \text { mTOR signaling } \\
\text { pathway } \downarrow\end{array}$ & [206] \\
\hline & $\begin{array}{l}\text { Diabetic mouse } \\
\text { model }\end{array}$ & $\begin{array}{c}\text { Antioxidant } \\
\text { Anti-inflammatory }\end{array}$ & $\begin{array}{c}\text { Cox-2, MCP-1, TNF- } \alpha \text { and } \\
\text { NF- } \kappa \mathrm{B} \downarrow, \text { Nrf2, GPx, SOD and } \\
\text { HO- } 1 \uparrow \\
\text { (renal tissue) }\end{array}$ & [207] \\
\hline & $\begin{array}{l}\text { Isolated mononuclear cells } \\
\text { from hemodialysis patients }\end{array}$ & Anti-inflammatory & TNF- $\alpha \downarrow$ (mononuclear cells) & [208] \\
\hline \multirow{5}{*}{ Rutin } & $\begin{array}{l}\text { Adenine-induced CKD rat } \\
\text { animal model }\end{array}$ & $\begin{array}{l}\text { Anti-fibrotic } \\
\text { Antioxidant }\end{array}$ & $\begin{array}{c}\text { Tubulointerstitial fibrosis } \downarrow \text {, } \\
\text { HO- } 1 \downarrow, \text { PLA- } 2 \downarrow \text { (renal tissue) }\end{array}$ & [217] \\
\hline & $\begin{array}{l}5 / 6 \text { nephrectomy and UUO } \\
\text { rat models }\end{array}$ & Anti-fibrotic & $\begin{array}{c}\text { Renal fibrosis } \downarrow \text {, TGF } \beta 1 \text {-Smad } \\
\text { signaling pathway } \downarrow\end{array}$ & {$[218,219]$} \\
\hline & $\begin{array}{l}\text { Endothelial cells of glomeruli } \\
\text { exposed to hyperglycemia }\end{array}$ & Antioxidant & $\begin{array}{c}\text { Nrf2 } \uparrow, \text { RhoA/ROCK } \\
\text { pathway } \downarrow\end{array}$ & [221] \\
\hline & $\begin{array}{l}\text { Alloxan-induced diabetic } \\
\text { nephropathy in rats }\end{array}$ & $\begin{array}{l}\text { Anti-fibrotic } \\
\text { Antioxidant }\end{array}$ & $\begin{array}{c}\text { TGF- } \beta 1 \downarrow, \text { podocin } \uparrow, \text { GRP78 } \\
\text { and CHOP } \downarrow \text {, ketoacidosis and } \\
\text { fibrosis } \downarrow \text {. } \\
\text { (renal tissue) }\end{array}$ & {$[222,223]$} \\
\hline & $\begin{array}{l}\text { STZ-induced diabetic } \\
\text { nephropathy in rats }\end{array}$ & Anti-fibrotic & $\begin{array}{c}\text { Collagen IV, laminin, TGF- } \beta 1 \text {, } \\
\text { p-Smad } 2 / 3,(\mathrm{CTGF}) \downarrow \\
\text { (renal tissue) }\end{array}$ & [224] \\
\hline
\end{tabular}


Table 2. Cont.

\begin{tabular}{|c|c|c|c|c|}
\hline $\begin{array}{l}\text { Small Bioactive } \\
\text { Compounds }\end{array}$ & Type of Study & Therapeutic Effect & Major Findings & References \\
\hline \multirow{4}{*}{ Proanthocyanidin } & $\begin{array}{c}\text { Mice subjected to } \\
\text { ischemia/reperfusion (I/R) }\end{array}$ & $\begin{array}{c}\text { Anti-fibrotic } \\
\text { Anti-inflammatory }\end{array}$ & $\begin{array}{c}\text { TGF- } \beta, \text { IL-6 and TNF } \alpha \downarrow \text {, } \\
\text { HMGB1/TLR4/p65/TGF- } \beta 1 \\
\text { signaling pathway } \downarrow \\
\text { (renal tissue) }\end{array}$ & [232] \\
\hline & $\begin{array}{c}\text { UUO mice and primary renal } \\
\text { tubular epithelial cells (PTEC), } \\
\text { normal rat kidney fibroblast } \\
\text { (NRK-49F) }\end{array}$ & Anti-fibrotic & $\begin{array}{c}\text { C3/HMGB1//TGF- } \beta 1 \downarrow \\
\text { (renal tissue) }\end{array}$ & [233] \\
\hline & $\begin{array}{l}\text { STZ-induced diabetic } \\
\text { nephropathy in rats }\end{array}$ & Anti-inflammatory & $\begin{array}{l}\text { AGEs/RAGE axis } \downarrow \\
\quad \text { (renal tissue) }\end{array}$ & [234] \\
\hline & $\begin{array}{l}\text { STZ-induced diabetic } \\
\text { nephropathy in rats }\end{array}$ & $\begin{array}{l}\text { Antioxidant } \\
\text { Anti-inflammatory } \\
\text { Anti-apoptotic }\end{array}$ & $\begin{array}{c}\text { MDA } \downarrow, \text { IL-6 } \downarrow \text {, GSH } \uparrow, \text { SOD, } \\
\text { Nrf2 } \uparrow, \text { GRP78), p-ERK, and } \\
\text { caspase } 12 \downarrow \\
\text { (renal tissue) }\end{array}$ & [235-238] \\
\hline \multirow{4}{*}{ Betulinic acid } & $\begin{array}{l}\text { Adenine-induced CKD rat } \\
\text { animal model }\end{array}$ & Anti-fibrotic & $\begin{array}{c}\text { TGF- } \beta,(\mathrm{CTGF}), \mathrm{FN}, \text { collagen } \\
\text { type I, and hydroxyproline } \downarrow \\
\text { (renal tissue) }\end{array}$ & [255] \\
\hline & $\begin{array}{c}\text { STZ-induced diabetic } \\
\text { nephropathy in rats and } \\
\text { glomerular mesangial cells } \\
\text { treated with high glucose level }\end{array}$ & $\begin{array}{l}\text { Anti-inflammatory } \\
\text { Anti-fibrotic }\end{array}$ & $\begin{array}{c}\text { I } \kappa \mathrm{B} \alpha, \mathrm{NF}-\kappa \mathrm{B} \text { pathway } \downarrow, \mathrm{FN} \\
\text { expression } \downarrow\end{array}$ & [256] \\
\hline & $\begin{array}{l}\text { STZ-induced diabetic } \\
\text { nephropathy in rats }\end{array}$ & $\begin{array}{l}\text { Anti-inflammatory } \\
\text { Antioxidant }\end{array}$ & $\begin{array}{c}\text { IL-6, IL- } 1 \beta, \text { TNF- } \alpha \downarrow \text { (serum } \\
\text { and kidney tissue) } \\
\text { AMPK } \uparrow / N F-\kappa B \downarrow / N r f 2 \uparrow\end{array}$ & [257] \\
\hline & $\begin{array}{l}\text { Membranous nephropathy } \\
\text { rat model }\end{array}$ & $\begin{array}{l}\text { Anti-inflammatory } \\
\text { Antioxidant }\end{array}$ & $\begin{array}{c}\text { NF-kB } \downarrow, \text { iNOS } \downarrow, \text { TNF- } \alpha \downarrow, \\
\text { Nrf2 } \uparrow, \mathrm{HO}-1 \uparrow, \text { and NQO1 } \uparrow \\
\text { (renal tissue) }\end{array}$ & [258] \\
\hline
\end{tabular}

TGF $\beta 1$ and SMAD 2/3, transforming growth factor-beta1 and small mothers against decapentaplegic $2 / 3$; TNF- $\alpha$, tumor necrosis factor alpha; SOD, superoxide dismutase; CAT, catalase; GSH, glutathione; TAC, total antioxidant capacity; TNF- $\alpha$, tumor necrosis factor alpha; IL-1 $\beta$, interleukin -1 beta; IL-6, interleukin-6; MCP-1, monocyte chemoattractant protein-1; TLR4, Toll-like receptor 4; NF- $\mathrm{kB}$, nuclear factor kappa B; PGC-1 $\alpha$, peroxisome proliferator-activated receptor-gamma coactivator $-1 \alpha$; FN, fibronectin; $\alpha$-SMA, smooth muscle alpha-actin snail1, zinc finger protein SNAI1; slug, zinc finger protein SNAI2; p-smad3, phosphorylated small mothers against decapentaplegic 3; ARAP1/AT1R; angiotensin II type 1 receptor-associated protein/angiotensin II type 1 receptor; LC3II, light chain 3-II; Beclin1, BECN1; $\alpha$-SMA, smooth muscle alpha-actin; iNOS, inducible nitric oxide synthase; MDA, malondialdehyde; PPARs, peroxisome proliferator-activated receptors; 20-HETE, 20hydroxyeicosatetraenoic acid; CYP4A, cytochrome P450 4a; MAPK, mitogen-activated protein kinases; Sirt3, sirtuin-3; CD38, cluster of differentiation 38; Nrf2, nuclear factor erythroid 2-related factor 2; HO-1, heme oxygenase-1; mTOR, mammalian target of rapamycin; MCP-1,monocyte chemoattractant protein-1; GPx, glutathione peroxidase; Cox-2; cyclooxygenase-2; PLA-2, phospholipases A2; RhoA, ras homolog gene family, member A; ROCK, Rho-associated protein kinase; GRP78, glucose-regulated protein78; CHOP, C/-EBP homologous protein; CTGF, connective tissue growth factor; HMGB1, high-mobility group box 1; p65, transcription factor p65; C3, complement 3; AGEs, advanced glycation end products; RAGE, receptor for advanced glycation end products; p-ERK, phosphorylated extracellular signal-regulated kinase; IKB $\alpha$; nuclear factor of kappa light polypeptide gene enhancer in B-cells inhibitor, alpha; AMPK, AMP-activated protein kinase; NQO1, NAD $(\mathrm{P}) \mathrm{H}$ : quinone oxidoreductase 1. 


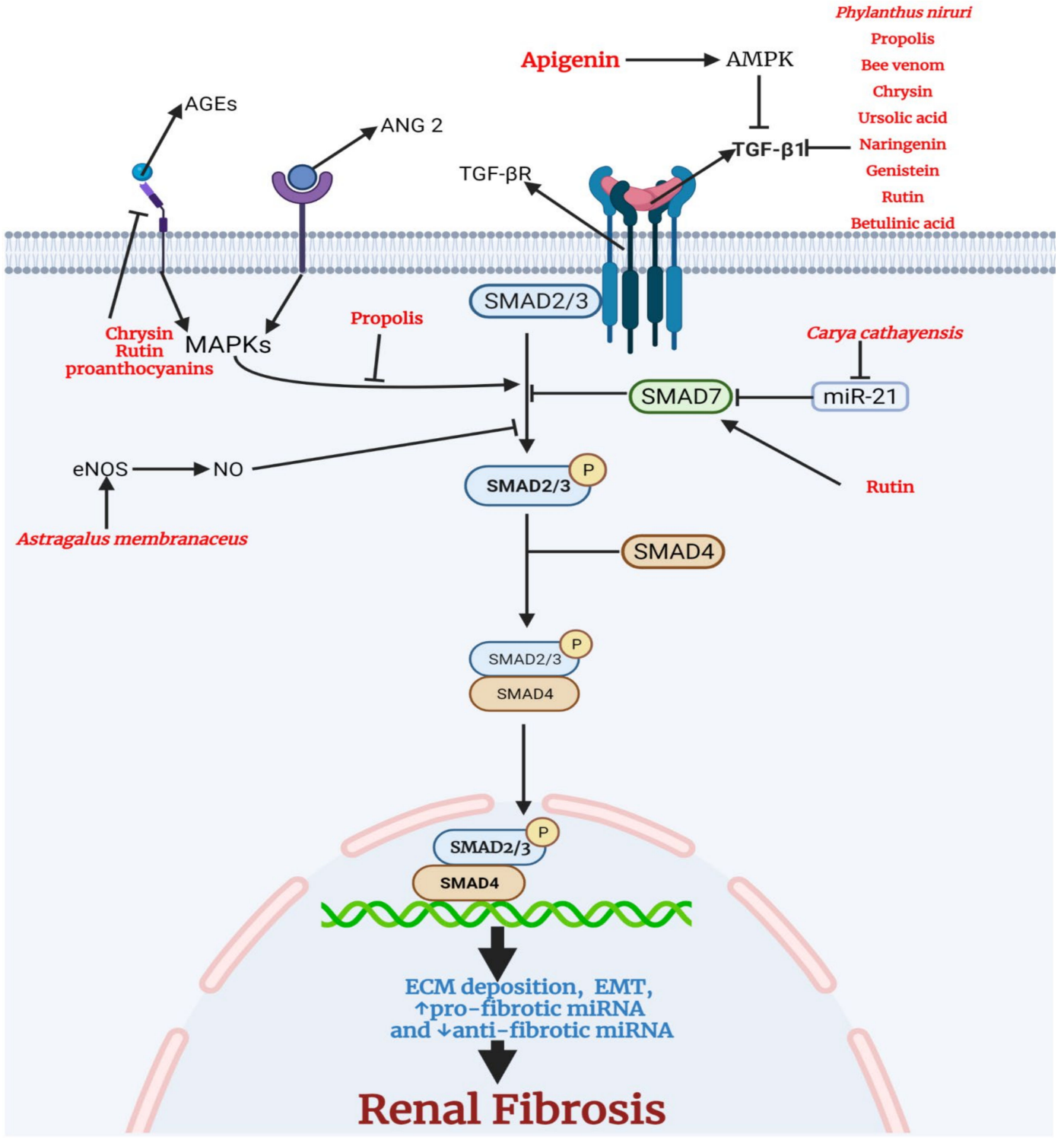

Figure 5. Medicinal plants and bioactive compounds with anti-fibrotic activity. The canonical transforming growth factor-beta1 (TGF $\beta 1$ ) pathway involves the binding of TGF $\beta 1$ to transforming growth factor-beta receptor (TGFBR). This leads to the phosphorylation and activation of small mothers against decapentaplegic 2/3 (SMAD 2/3). SMAD7, the inhibitory SMAD, inhibits the activation of SMAD 2/3 by the TGFBR. SMAD 7 is negatively regulated by microRNA-21 (miR21). Active SMAD 2/3 binds the common SMAD (SMAD 4) and translocates to the nucleus to drive the transcription of genes encoding proteins that make up the extracellular matrix, proteins that are involved in epithelial to mesenchymal transition, and pro-fibrotic miRNA. The advanced glycation end products (AGEs) and angiotensin II (ANG 2) drive the activation of MAPKs that activate SMAD 2/3. Nitric oxide (NO) is involved in the inhibition of SMAD 2/3. Chrysin, rutin, and proanthocyanins inhibit the receptor for advanced glycation end products (RAGE), thus reducing the activation of MAPKs. In addition, propolis inhibits the activation of SMAD 2/3 by MAPKs. Astragalus membranaceus increases endothelial nitric oxide synthase (eNOS) and the level NO. A high level of NO inhibits the activation of SMAD 2/3. Rutin directly activates SMAD 7, leading to a reduction in activation of SMAD 2/3. Carya cathayensis inhibits miR-21, the negative modulator of SMAD7. Phylanthus niruri, propolis, bee venom, chrysin, ursolic acid, naringenin, genistein, rutin, betulinic acid reduce the level of TGF $\beta 1$, thus inhibiting the activation of TGFBR. Apigenin activates AMPK leading to a decrease in the level of TGF $\beta 1$. 


\section{Conclusions}

In this review, we have outlined the considerable benefits of many bioactive substances in the primary prevention of CKD, as well as in delaying the progression of CKD. These substances may also help manage and prevent two of the predominant common causes of CKD: diabetic nephropathy and renal fibrosis. Several biological pathways and mechanisms that contribute to the initiation and progression of CKD include the NF- $\mathrm{KB}$ pathway, mitochondrial activity, autophagy, and the TGF- $\beta$ pathway. These substances may work by inhibiting oxidative stress, inflammation, and fibrosis, among other things, in the prevention and treatment of CKD. However, further research is needed to determine the particular mechanism through which these compounds exert their protective benefits. Although clinical trials have indicated that these natural antioxidants also can help manage and delay the progression of CKD, more prospective studies are needed, especially to determine the safety and side effects of these compounds. This paucity of clinical studies could be attributed to various causes, including a lack of finances, concerns about the compounds' side effects and safety, and possibly a belief that pharmaceutical therapies are more vital.

Author Contributions: M.M. and M.M.A. contributed to literature mining and manuscript writing. S.S.A.-R. directed the project and edited the manuscript. All authors have read and agreed to the published version of the manuscript.

Funding: The authors thank the Deanship of Scientific Research at KSU for funding this work through the research group project number RGP-1440-085.

Acknowledgments: We are grateful to the Deanship of Scientific Research at KSU for funding this work through the research group project number RGP-1440-085.

Conflicts of Interest: The authors declare no conflict of interest.

\section{References}

1. Hill, N.R.; Fatoba, S.T.; Oke, J.L.; Hirst, J.A.; O'Callaghan, C.A.; Lasserson, D.S.; Hobbs, F.R. Global prevalence of chronic kidney disease-A systematic review and meta-analysis. PLoS ONE 2016, 11, e0158765. [CrossRef]

2. Gyurászová, M.; Gurecká, R.; Bábíčková, J.; Tóthová, L'. Oxidative stress in the pathophysiology of kidney disease: Implications for noninvasive monitoring and identification of biomarkers. Oxidative Med. Cell. Longev. 2020, 2020, 5478708. [CrossRef] [PubMed]

3. Fanelli, C.; Noreddin, A.; Nunes, A. Inflammation in Nonimmune-Mediated Chronic Kidney. In Chronic Kidney Disease: From Pathophysiology to Clinical Improvements; Intechopen: London, UK, 2018; 153p.

4. Vaidya, S.R.; Aeddula, N.R. Chronic Renal Failure; StatPearls Publishing: Treasure Islands, FL, USA, 2019.

5. Yuan, H.; Ma, Q.; Ye, L.; Piao, G. The Traditional Medicine and Modern Medicine from Natural Products. Molecules 2016, 21, 559. [CrossRef] [PubMed]

6. Samadi, K.; Naghibi, M.; Shabestari, M.; Sharifipour, F.; Khajeh Dalooee, M.; Raeesi, V.; Nik, S.M.; Samadi, M. Evaluation the Effects of Alpha-tocopherol in Comparison with N-acetylcystein for Prevention of Contrast Induced Nephropathy (CIN) in CKD Patients. Iran. J. Kidney Dis. 2020, 14, 26-30. [PubMed]

7. Lai, S.; Petramala, L.; Muscaritoli, M.; Cianci, R.; Mazzaferro, S.; Mitterhofer, A.P.; Pasquali, M.; D’Ambrosio, V.; Carta, M.; Ansuini, M.; et al. $\alpha$-lipoic acid in patients with autosomal dominant polycystic kidney disease. Nutrition 2020, 71,110594 . [CrossRef]

8. Andrade-Oliveira, V.; Foresto-Neto, O.; Watanabe, I.K.M.; Zatz, R.; Câmara, N.O.S. Inflammation in renal diseases: New and old players. Front. Pharmacol. 2019, 10, 1192. [CrossRef]

9. Jiang, M.; Bai, M.; Lei, J.; Xie, Y.; Xu, S.; Jia, Z.; Zhang, A. Mitochondrial dysfunction and the AKI-to-CKD transition. Am. J. Physiol. Ren. Physiol. 2020, 319, F1105-F1116. [CrossRef]

10. Uddin, M.J.; Kim, E.H.; Hannan, M.; Ha, H. Pharmacotherapy against Oxidative stress in chronic kidney disease: Promising small molecule natural products targeting Nrf2-HO-1 signaling. Antioxidants 2021, 10, 258. [CrossRef]

11. Chen, D.-Q.; Hu, H.-H.; Wang, Y.-N.; Feng, Y.-L.; Cao, G.; Zhao, Y.-Y. Natural products for the prevention and treatment of kidney disease. Phytomedicine 2018, 50, 50-60. [CrossRef]

12. Roumeliotis, S.; Roumeliotis, A.; Dounousi, E.; Eleftheriadis, T.; Liakopoulos, V. Dietary antioxidant supplements and uric acid in chronic kidney disease: A review. Nutrients 2019, 11, 1911. [CrossRef]

13. Rapa, S.F.; Di Iorio, B.R.; Campiglia, P.; Heidland, A.; Marzocco, S. Inflammation and oxidative stress in chronic kidney disease-Potential therapeutic role of minerals, vitamins and plant-derived metabolites. Int. J. Mol. Sci 2020, 21, 263. [CrossRef] 
14. Souza, A.C.; Tsuji, T.; Baranova, I.N.; Bocharov, A.V.; Wilkins, K.J.; Street, J.M.; Alvarez-Prats, A.; Hu, X.; Eggerman, T.; Yuen, P.S. TLR 4 mutant mice are protected from renal fibrosis and chronic kidney disease progression. Physiol. Rep. 2015, 3, e12558. [CrossRef]

15. Leemans, J.C.; Kors, L.; Anders, H.-J.; Florquin, S. Pattern recognition receptors and the inflammasome in kidney disease. Nat. Rev. Nephrol. 2014, 10, 398-414. [CrossRef]

16. Kawasaki, T.; Kawai, T. Toll-like receptor signaling pathways. Front. Immunol. 2014, 5, 461. [CrossRef]

17. Ma, J.; Chadban, S.J.; Zhao, C.Y.; Chen, X.; Kwan, T.; Panchapakesan, U.; Pollock, C.A.; Wu, H. TLR4 activation promotes podocyte injury and interstitial fibrosis in diabetic nephropathy. PLoS ONE 2014, 9, e97985. [CrossRef]

18. Yu, M.; Wang, H.; Ding, A.; Golenbock, D.T.; Latz, E.; Czura, C.J.; Fenton, M.J.; Tracey, K.J.; Yang, H. HMGB1 signals through toll-like receptor (TLR) 4 and TLR2. Shock 2006, 26, 174-179. [CrossRef]

19. Schaefer, L.; Babelova, A.; Kiss, E.; Hausser, H.-J.; Baliova, M.; Krzyzankova, M.; Marsche, G.; Young, M.F.; Mihalik, D.; Götte, M. The matrix component biglycan is proinflammatory and signals through Toll-like receptors 4 and 2 in macrophages. J. Clin. Investig. 2005, 115, 2223-2233. [CrossRef]

20. Akira, S.; Takeda, K. Toll-like receptor signalling. Nat. Rev. Immunol. 2004, 4, 499-511. [CrossRef]

21. Dhillon, B.; Aleithan, F.; Abdul-Sater, Z.; Abdul-Sater, A.A. The evolving role of TRAFs in mediating inflammatory responses Front. Immunol. 2019, 10, 104. [CrossRef]

22. Rangan, G.; Wang, Y.; Harris, D. NF-kappaB signalling in chronic kidney disease. Front. Biosci. 2009, 14, 3496-3522. [CrossRef]

23. Wajant, H.; Siegmund, D. TNFR1 and TNFR2 in the control of the life and death balance of macrophages. Front. Cell Dev. Biol. 2019, 7, 91. [CrossRef]

24. Micheau, O.; Tschopp, J. Induction of TNF receptor I-mediated apoptosis via two sequential signaling complexes. Cell 2003, 114, 181-190. [CrossRef]

25. Kaushal, G.P.; Chandrashekar, K.; Juncos, L.A.; Shah, S.V. Autophagy function and regulation in kidney disease. Biomolecules 2020, 10, 100. [CrossRef]

26. Yun, H.R.; Jo, Y.H.; Kim, J.; Shin, Y.; Kim, S.S.; Choi, T.G. Roles of autophagy in oxidative stress. Int. J. Mol. Sci. 2020, 21, 3289. [CrossRef]

27. Birgisdottir, Å.B.; Mouilleron, S.; Bhujabal, Z.; Wirth, M.; Sjøttem, E.; Evjen, G.; Zhang, W.; Lee, R.; O’Reilly, N.; Tooze, S.A. Members of the autophagy class III phosphatidylinositol 3-kinase complex I interact with GABARAP and GABARAPL1 via LIR motifs. Autophagy 2019, 15, 1333-1355. [CrossRef]

28. Kim, J.; Kundu, M.; Viollet, B.; Guan, K.-L. AMPK and mTOR regulate autophagy through direct phosphorylation of Ulk1. Nat. Cell Biol. 2011, 13, 132-141. [CrossRef]

29. Peters, L.J.; Floege, J.; Biessen, E.A.; Jankowski, J.; van der Vorst, E.P. MicroRNAs in chronic kidney disease: Four candidates for clinical application. Int. J. Mol. Sci. 2020, 21, 6547. [CrossRef]

30. Sun, J.; Li, Z.P.; Zhang, R.Q.; Zhang, H.M. Repression of miR-217 protects against high glucose-induced podocyte injury and insulin resistance by restoring PTEN-mediated autophagy pathway. Biochem. Biophys. Res. Commun. 2017, 483, 318-324. [CrossRef]

31. Ueno, T.; Komatsu, M. Monitoring autophagy flux and activity: Principles and applications. Bioessays 2020, 42, 2000122. [CrossRef]

32. Galvan, D.L.; Green, N.H.; Danesh, F.R. The hallmarks of mitochondrial dysfunction in chronic kidney disease. Kidney Int. 2017, 92, 1051-1057. [CrossRef]

33. Kim, Y.; Park, C.W. Adenosine monophosphate-activated protein kinase in diabetic nephropathy. Kidney Res. Clin. Pract. 2016, 35 , 69-77. [CrossRef] [PubMed]

34. Zhang, J.; Wang, Y.; Liu, X.; Dagda, R.K.; Zhang, Y. How AMPK and PKA interplay to regulate mitochondrial function and survival in models of ischemia and diabetes. Oxidative Med. Cell. Longev. 2017, 2017. [CrossRef] [PubMed]

35. Puchałowicz, K.; Rać, M.E. The Multifunctionality of CD36 in Diabetes Mellitus and Its Complications-Update in Pathogenesis. Treat. Monit. Cells. 2020, 9, 1877.

36. Wu, J.; Jin, Z.; Zheng, H.; Yan, L.-J. Sources and implications of NADH/NAD+ redox imbalance in diabetes and its complications. Diabetes Metab. Syndr. Obes. Targets Ther. 2016, 9, 145.

37. Xie, N.; Zhang, L.; Gao, W.; Huang, C.; Huber, P.E.; Zhou, X.; Li, C.; Shen, G.; Zou, B. NAD+ metabolism: Pathophysiologic mechanisms and therapeutic potential. Signal Transduct. Target. Ther. 2020, 5, 1-37. [CrossRef]

38. Guo, K.; Lu, J.; Huang, Y.; Wu, M.; Zhang, L.; Yu, H.; Zhang, M.; Bao, Y.; He, J.C.; Chen, H. Protective role of PGC-1 $\alpha$ in diabetic nephropathy is associated with the inhibition of ROS through mitochondrial dynamic remodeling. PLoS ONE 2015, 10, e0125176. [CrossRef]

39. Ayanga, B.A.; Badal, S.S.; Wang, Y.; Galvan, D.L.; Chang, B.H.; Schumacker, P.T.; Danesh, F.R. Dynamin-Related Protein 1 Deficiency Improves Mitochondrial Fitness and Protects against Progression of Diabetic Nephropathy. J. Am. Soc. Nephrol. 2016, 27, 2733-2747. [CrossRef]

40. Aon, M.A.; Bhatt, N.; Cortassa, S.C. Mitochondrial and cellular mechanisms for managing lipid excess. Front. Physiol. 2014, 5, 282. [CrossRef]

41. Zhan, M.; Usman, I.M.; Sun, L.; Kanwar, Y.S. Disruption of renal tubular mitochondrial quality control by Myo-inositol oxygenase in diabetic kidney disease. J. Am. Soc. Nephrol. 2015, 26, 1304-1321. [CrossRef] 
42. Rajpathak, S.N.; Gunter, M.J.; Wylie-Rosett, J.; Ho, G.Y.; Kaplan, R.C.; Muzumdar, R.; Rohan, T.E.; Strickler, H.D. The role of insulin-like growth factor-I and its binding proteins in glucose homeostasis and type 2 diabetes. Diabetes Metab. Res. Rev. 2009, 25, 3-12. [CrossRef]

43. Boucher, J.; Kleinridders, A.; Kahn, C.R. Insulin receptor signaling in normal and insulin-resistant states. Cold Spring Harb. Perspect. Biol. 2014, 6, a009191. [CrossRef]

44. Huang, X.; Liu, G.; Guo, J.; Su, Z. The PI3K/AKT pathway in obesity and type 2 diabetes. Int. J. Biol. Sci. 2018, 14, 1483. [CrossRef]

45. Lu, M.; Wang, P.; Qiao, Y.; Jiang, C.; Ge, Y.; Flickinger, B.; Malhotra, D.K.; Dworkin, L.D.; Liu, Z.; Gong, R. GSK3ß-mediated Keap1-independent regulation of Nrf2 antioxidant response: A molecular rheostat of acute kidney injury to chronic kidney disease transition. Redox Biol. 2019, 26, 101275. [CrossRef]

46. Adelusi, T.I.; Du, L.; Hao, M.; Zhou, X.; Xuan, Q.; Apu, C.; Sun, Y.; Lu, Q.; Yin, X. Keap1/Nrf2/ARE signaling unfolds therapeutic targets for redox imbalanced-mediated diseases and diabetic nephropathy. Biomed. Pharmacother. 2020, 123, 109732. [CrossRef]

47. Stenvinkel, P.; Chertow, G.M.; Devarajan, P.; Levin, A.; Andreoli, S.P.; Bangalore, S.; Warady, B.A. Chronic Inflammation in Chronic Kidney Disease Progression: Role of Nrf2. Kidney Int. Rep. 2021, 6, 1775-1787. [CrossRef]

48. Liu, Y. Cellular and molecular mechanisms of renal fibrosis. Nat. Rev. Nephrol. 2011, 7, 684-696. [CrossRef]

49. Sureshbabu, A.; Muhsin, S.A.; Choi, M.E. TGF- $\beta$ signaling in the kidney: Profibrotic and protective effects. Am. J. Physiol. Ren. Physiol. 2016, 310, F596-F606. [CrossRef]

50. Gu, Y.-Y.; Liu, X.-S.; Huang, X.-R.; Yu, X.-Q.; Lan, H.-Y. Diverse role of TGF- $\beta$ in kidney disease. Front. Cell Dev. Biol. $2020,8,123$. [CrossRef]

51. Meng, X.-M.; Tang, P.M.-K.; Li, J.; Lan, H.Y. TGF- $\beta$ /Smad signaling in renal fibrosis. Front. Physiol. 2015, 6, 82. [CrossRef]

52. Murayama, K.; Kato-Murayama, M.; Itoh, Y.; Miyazono, K.; Miyazawa, K.; Shirouzu, M. Structural basis for inhibitory effects of Smad7 on TGF- $\beta$ family signaling. J. Struct. Biol. 2020, 212, 107661. [CrossRef]

53. Lin, L.; Gan, H.; Zhang, H.; Tang, W.; Sun, Y.; Tang, X.; Kong, D.; Zhou, J.; Wang, Y.; Zhu, Y. MicroRNA-21 inhibits SMAD7 expression through a target sequence in the 3'untranslated region and inhibits proliferation of renal tubular epithelial cells. Mol. Med. Rep. 2014, 10, 707-712. [CrossRef]

54. Li, J.H.; Huang, X.R.; Zhu, H.J.; Oldfield, M.; Cooper, M.; Truong, L.D.; Johnson, R.J.; Lan, H.Y. Advanced glycation end products activate Smad signaling via TGF- $\beta$-dependent and-independent mechanisms: Implications for diabetic renal and vascular disease. FASEB J. 2004, 18, 176-178. [CrossRef]

55. Rodríguez-Vita, J.; Sánchez-López, E.; Esteban, V.; Rupérez, M.; Egido, J.; Ruiz-Ortega, M. Angiotensin II activates the Smad pathway in vascular smooth muscle cells by a transforming growth factor- $\beta$-independent mechanism. Circulation 2005, 111, 2509-2517. [CrossRef]

56. Lee, S.-Y.; Kim, S.I.; Choi, M.E. Therapeutic targets for treating fibrotic kidney diseases. Transl. Res. 2015, 165, 512-530. [CrossRef]

57. Chauveau, P.; Koppe, L.; Combe, C.; Lasseur, C.; Trolonge, S.; Aparicio, M. Vegetarian diets and chronic kidney disease. Nephrol. Dial. Transplant. 2019, 34, 199-207. [CrossRef]

58. Baracho, N.C.; Monteiro, N.F.; Borges, M.G.; Arguelho, R.R. Effect of aqueous extract of the Vigna angularis in rats subjected to an experimental model of moderate chronic kidney disease. Acta Cir. Bras. 2016, 31, 527-532. [CrossRef]

59. Zhang, H.W.; Lin, Z.X.; Xu, C.; Leung, C.; Chan, L.S. Astragalus (a traditional Chinese medicine) for treating chronic kidney disease. Cochrane Database Syst. Rev. 2014, 10, Cd008369. [CrossRef]

60. Parveen, A.; Jin, M.; Kim, S.Y. Bioactive phytochemicals that regulate the cellular processes involved in diabetic nephropathy. Phytomedicine 2018, 39, 146-159. [CrossRef] [PubMed]

61. Giribabu, N.; Karim, K.; Kilari, E.K.; Salleh, N. Phyllanthus niruri leaves aqueous extract improves kidney functions, ameliorates kidney oxidative stress, inflammation, fibrosis and apoptosis and enhances kidney cell proliferation in adult male rats with diabetes mellitus. J. Ethnopharmacol. 2017, 205, 123-137. [CrossRef] [PubMed]

62. Wu, X.; Ding, X.; Ding, Z.; Jia, P. Total Flavonoids from Leaves of Carya Cathayensis Ameliorate Renal Fibrosis via the miR21/Smad7 Signaling Pathway. Cell Physiol. Biochem. 2018, 49, 1551-1563. [CrossRef] [PubMed]

63. Chen, Y.; Cai, G.; Sun, X.; Chen, X. Treatment of chronic kidney disease using a traditional Chinese medicine, Flos Abelmoschus manihot (Linnaeus) Medicus (Malvaceae). Clin Exp Pharm. Physiol 2016, 43, 145-148. [CrossRef]

64. Yu, J.Y.; Xiong, N.N. Pathogenic factor (Dampness-heat) of glomerulopathy. Zhongguo Zhong Xi Yi Jie He Za Zhi 1992, 12, 458-460.

65. Zhou, L.; An, X.F.; Teng, S.C.; Liu, J.S.; Shang, W.B.; Zhang, A.H.; Yuan, Y.G.; Yu, J.Y. Pretreatment with the total flavone glycosides of Flos Abelmoschus manihot and hyperoside prevents glomerular podocyte apoptosis in streptozotocin-induced diabetic nephropathy. J. Med. Food 2012, 15, 461-468. [CrossRef]

66. Mao, Z.M.; Shen, S.M.; Wan, Y.G.; Sun, W.; Chen, H.L.; Huang, M.M.; Yang, J.J.; Wu, W.; Tang, H.T.; Tang, R.M. Huangkui capsule attenuates renal fibrosis in diabetic nephropathy rats through regulating oxidative stress and p38MAPK/Akt pathways, compared to $\alpha$-lipoic acid. J. Ethnopharmacol. 2015, 173, 256-265. [CrossRef]

67. Zhao, Q.; Wan, Y.G.; Sun, W.; Wang, C.J.; Wei, Q.X.; Chen, H.L.; Meng, X.J. Effects of huangkui capsule on renal inflammatory injury by intervening p38MAPK signaling pathway in rats with adriamycin-induced nephropathy. Zhongguo Zhong Yao Za Zhi 2012, 37, 2926-2934.

68. Tu, Y.; Sun, W.; Wan, Y.G.; Che, X.Y.; Pu, H.P.; Yin, X.J.; Chen, H.L.; Meng, X.J.; Huang, Y.R.; Shi, X.M. Huangkui capsule, an extract from Abelmoschus manihot (L.) medic, ameliorates adriamycin-induced renal inflammation and glomerular injury via inhibiting p38MAPK signaling pathway activity in rats. J. Ethnopharmacol. 2013, 147, 311-320. [CrossRef] 
69. Carney, E.F. Glomerular disease. Antiproteinuric efficacy of A. manihot superior to losartan. Nat. Rev. Nephrol. 2014, 10, 300. [CrossRef]

70. Huang, H.; Luo, S.h.; Huang, D.c.; Cheng, S.j.; Cao, C.j.; Chen, G.t. Immunomodulatory activities of proteins from Astragalus membranaceus waste. J. Sci. Food Agric. 2019, 99, 4174-4181. [CrossRef]

71. Sarikurkcu, C.; Zengin, G. Polyphenol profile and biological activity comparisons of different parts of Astragalus macrocephalus subsp. finitimus from Turkey. Biology 2020, 9, 231. [CrossRef]

72. Lee, E.J.; Lee, D.B.; Song, B.N.; Park, B.R.; Lee, S.H.; Choi, J.H.; Park, S.Y. Physicochemical Properties and Anti-inflammatory Effects of Astragalus membranaceus (Fisch.) Bunge Fermented by Aspergillus awamori. Korean J. Med. Crop. Sci. 2020, 28, 347-353. [CrossRef]

73. Hui, D.; Rui-Zhi, T.; Jian-Chun, L.; Xia, Z.; Dan, W.; Jun-Ming, F.; Li, W. Astragalus propinquus Schischkin and Panax notoginseng $(A \& P)$ compound relieved cisplatin-induced acute kidney injury through inhibiting the mincle maintained macrophage inflammation. J. Ethnopharmacol. 2020, 252, 112637.

74. Shahzad, M.; Small, D.M.; Morais, C.; Wojcikowski, K.; Shabbir, A.; Gobe, G.C. Protection against oxidative stress-induced apoptosis in kidney epithelium by Angelica and Astragalus. J. Ethnopharmacol. 2016, 179, 412-419. [CrossRef]

75. Meng, L.; Qu, L.; Tang, J.; Cai, S.-Q.; Wang, H.; Li, X. A combination of Chinese herbs, Astragalus membranaceus var. mongholicus and Angelica sinensis, enhanced nitric oxide production in obstructed rat kidney. Vasc. Pharmacol. 2007, 47, 174-183. [CrossRef]

76. Alshinnawy, A.; Elsayed, W.; Taha, A.; Sayed, A.; Salem, A. Astragalus membranaceus and Punica granatum alleviate infertility and kidney dysfunction induced by aging in male rats. Turk. J. Biol. 2020, 44, 166-175. [CrossRef]

77. Okuda, M.; Horikoshi, S.; Matsumoto, M.; Tanimoto, M.; Yasui, H.; Tomino, Y. Beneficial effect of Astragalus membranaceus on estimated glomerular filtration rate in patients with progressive chronic kidney disease. Hong Kong J. Nephrol. 2012, 14, 17-23. [CrossRef]

78. Li, M.; Wang, W.; Xue, J.; Gu, Y.; Lin, S. Meta-analysis of the clinical value of Astragalus membranaceus in diabetic nephropathy. J. Ethnopharmacol. 2011, 133, 412-419. [CrossRef] [PubMed]

79. Kim, J.; Moon, E.; Kwon, S. Effect of Astragalus membranaceus extract on diabetic nephropathy. Endocrinol. Diabetes Metab. Case Rep. 2014, 2014, 14-0063. [CrossRef] [PubMed]

80. Wen, D.; Tan, R.-Z.; Zhao, C.-Y.; Li, J.-C.; Zhong, X.; Diao, H.; Lin, X.; Duan, D.D.; Fan, J.-M.; Xie, X.-S. Astragalus mongholicus Bunge and Panax notoginseng (Burkill) FH Chen Formula for Renal Injury in Diabetic Nephropathy-In Vivo and In Vitro Evidence for Autophagy Regulation. Front. Pharmacol. 2020, 11, 732. [CrossRef] [PubMed]

81. Zuo, C.; Xie, X.S.; Qiu, H.Y.; Deng, Y.; Zhu, D.; Fan, J.M. Astragalus mongholicus ameliorates renal fibrosis by modulating HGF and TGF-beta in rats with unilateral ureteral obstruction. J. Zhejiang Univ. Sci. B 2009, 10, 380-390. [CrossRef]

82. Zuo, C.; Xie, X.; Deng, Y.; Fan, J. Effect of Astragalus mongholicus on expression of transforming growth factor- beta1 in SD rats with unilateral ureteral occlusion. Zhongguo Zhong Yao Za Zhi 2009, 34, 193-198.

83. Wang, H.; Li, J.; Yu, L.; Zhao, Y.; Ding, W. Antifibrotic effect of the Chinese herbs, Astragalus mongholicus and Angelica sinensis, in a rat model of chronic puromycin aminonucleoside nephrosis. Life Sci 2004, 74, 1645-1658. [CrossRef]

84. Hong, X.P.; Zhang, X.Z.; He, X.L.; Huang, X.Z.; Chen, H.R.; Wang, Y.Z. Effect of Astragalus mongholicus on renal gene expression profile in mice with diabetic nephropathy. Zhongguo Zhong Yao Za Zhi 2008, 33, 676-680.

85. Sato, S.; Hori, Y.; Yamate, J.; Saito, T.; Kurasaki, M.; Hatai, A. Protective effect of dietary azuki bean (Vigna angularis) seed coats against renal interstitial fibrosis of rats induced by cisplatin. Nutrition 2005, 21, 504-511. [CrossRef]

86. Sato, S.; Kataoka, S.; Kimura, A.; Mukai, Y. Azuki bean (Vigna angularis) extract reduces oxidative stress and stimulates autophagy in the kidneys of streptozotocin-induced early diabetic rats. Can. J. Physiol. Pharm. 2016, 94, 1298-1303. [CrossRef]

87. Sato, S.; Yamate, J.; Hori, Y.; Hatai, A.; Nozawa, M.; Sagai, M. Protective effect of polyphenol-containing azuki bean (Vigna angularis) seed coats on the renal cortex in streptozotocin-induced diabetic rats. J. Nutr. Biochem. 2005, 16, 547-553. [CrossRef]

88. Kurek-Górecka, A.; Górecki, M.; Rzepecka-Stojko, A.; Balwierz, R.; Stojko, J. Bee Products in Dermatology and Skin Care. Molecules 2020, 25, 556. [CrossRef]

89. Premratanachai, P.; Chanchao, C. Review of the anticancer activities of bee products. Asian Pac. J. Trop. Biomed. 2014, 4, 337-344. [CrossRef]

90. Zhou, W.; Zhao, Y.; Yan, Y.; Mi, J.; Lu, L.; Luo, Q.; Li, X.; Zeng, X.; Cao, Y. Antioxidant and immunomodulatory activities in vitro of polysaccharides from bee collected pollen of Chinese wolfberry. Int. J. Biol. Macromol. 2020, 163, 190-199. [CrossRef]

91. Cornara, L.; Biagi, M.; Xiao, J.; Burlando, B. Therapeutic Properties of Bioactive Compounds from Different Honeybee Products. Front. Pharm. 2017, 8, 412. [CrossRef]

92. Silveira, M.A.D.; Teles, F.; Berretta, A.A.; Sanches, T.R.; Rodrigues, C.E.; Seguro, A.C.; Andrade, L. Effects of Brazilian green propolis on proteinuria and renal function in patients with chronic kidney disease: A randomized, double-blind, placebocontrolled trial. BMC Nephrol. 2019, 20, 140. [CrossRef]

93. Chang, J.F.; Hsieh, C.Y.; Lu, K.C.; Chen, Y.W.; Liang, S.S.; Lin, C.C.; Hung, C.F.; Liou, J.C.; Wu, M.S. Therapeutic Targeting of Aristolochic Acid Induced Uremic Toxin Retention, SMAD 2/3 and JNK/ERK Pathways in Tubulointerstitial Fibrosis: Nephroprotective Role of Propolis in Chronic Kidney Disease. Toxins 2020, 12, 364. [CrossRef]

94. Pasupuleti, V.R.; Sammugam, L.; Ramesh, N.; Gan, S.H. Honey, Propolis, and Royal Jelly: A Comprehensive Review of Their Biological Actions and Health Benefits. Oxidative Med. Cell. Longev. 2017, 2017, 1259510. [CrossRef] 
95. Sun, C.; Wu, Z.; Wang, Z.; Zhang, H. Effect of ethanol/water solvents on phenolic profiles and antioxidant properties of Beijing propolis extracts. Evid.-Based Complementary Altern. Med. 2015, 2015, 595393. [CrossRef]

96. Andrade, J.K.S.; Denadai, M.; de Oliveira, C.S.; Nunes, M.L.; Narain, N. Evaluation of bioactive compounds potential and antioxidant activity of brown, green and red propolis from Brazilian northeast region. Food Res. Int. 2017, 101, 129-138. [CrossRef]

97. Zhang, C.; Shen, X.; Chen, J.; Jiang, X.; Hu, F. Identification of free radical scavengers from Brazilian green propolis using off-line HPLC-DPPH assay and LC-MS. J. Food Sci. 2017, 82, 1602-1607. [CrossRef]

98. Teles, F.; da Silva, T.M.; da Cruz Júnior, F.P.; Honorato, V.H.; de Oliveira Costa, H.; Barbosa, A.P.; de Oliveira, S.G.; Porfírio, Z.; Libório, A.B.; Borges, R.L.; et al. Brazilian red propolis attenuates hypertension and renal damage in 5/6 renal ablation model. PLoS ONE 2015, 10, e0116535. [CrossRef]

99. Agung, S.; Bambang, P.; Ambar, M.; Suroto, S. Nephro-Protective Effect of the Indonesian Propolis Extract on Unilateral Renal Ureter Obstructive Damage. In Proceedings of the Mid-International Conference on Public Health 2018, Surakarta, Indonesia, 18-19 April 2018; p. 240.

100. Sameni, H.R.; Ramhormozi, P.; Bandegi, A.R.; Taherian, A.A.; Mirmohammadkhani, M.; Safari, M. Effects of ethanol extract of propolis on histopathological changes and anti-oxidant defense of kidney in a rat model for type 1 diabetes mellitus. J. Diabetes Investig. 2016, 7, 506-513. [CrossRef]

101. Silveira, M.; Teles, F.; Melo, E.; Borges, V.; Miranda, F.; Dutra, F.; Berretta, A.; Cezar, R.; Silva, J.; Santos, H. P1574 Effects of Brazilian Green Propolis Extract (EPP-AF) on Inflammation in Hemodialysis Patients. Nephrol. Dial. Transplant. 2020, 35 (Suppl. S3), gfaa142. [CrossRef]

102. Lee, E.-J.; Kang, M.-K.; Kim, D.Y.; Kim, Y.-H.; Oh, H.; Kang, Y.-H. Chrysin inhibits advanced glycation end products-induced kidney fibrosis in renal mesangial cells and diabetic kidneys. Nutrients 2018, 10, 882. [CrossRef]

103. Ali, B.H.; Adham, S.A.; Al Za'abi, M.; Waly, M.I.; Yasin, J.; Nemmar, A.; Schupp, N. Ameliorative effect of chrysin on adenineinduced chronic kidney disease in rats. PLOS ONE 2015, 10, e0125285. [CrossRef]

104. Oktem, F.; Ozguner, F.; Sulak, O.; Olgar, Ş.; Akturk, O.; Yilmaz, H.R.; Altuntas, I. Lithium-induced renal toxicity in rats: Protection by a novel antioxidant caffeic acid phenethyl ester. Mol. Cell. Biochem. 2005, 277, 109-115. [CrossRef] [PubMed]

105. Chao, C.y.; Mong, M.c.; Chan, K.c.; Yin, M.c. Anti-glycative and anti-inflammatory effects of caffeic acid and ellagic acid in kidney of diabetic mice. Mol. Nutr. Food Res. 2010, 54, 388-395. [CrossRef] [PubMed]

106. Granados-Pineda, J.; Uribe-Uribe, N.; García-López, P.; Ramos-Godinez, M.D.P.; Rivero-Cruz, J.F.; Pérez-Rojas, J.M. Effect of Pinocembrin Isolated from Mexican Brown Propolis on Diabetic Nephropathy. Molecules 2018, 23, 852. [CrossRef] [PubMed]

107. Duffy, C.; Sorolla, A.; Wang, E.; Golden, E.; Woodward, E.; Davern, K.; Ho, D.; Johnstone, E.; Pfleger, K.; Redfern, A. Honeybee venom and melittin suppress growth factor receptor activation in HER2-enriched and triple-negative breast cancer. NPJ Precis. Oncol. 2020, 4, 1-16. [CrossRef]

108. An, H.J.; Kim, K.H.; Lee, W.R.; Kim, J.Y.; Lee, S.J.; Pak, S.C.; Han, S.M.; Park, K.K. Anti-fibrotic effect of natural toxin bee venom on animal model of unilateral ureteral obstruction. Toxins 2015, 7, 1917-1928. [CrossRef]

109. Mafra, D.; Borges, N.; Alvarenga, L.; Esgalhado, M.; Cardozo, L.; Lindholm, B.; Stenvinkel, P. Dietary components that may influence the disturbed gut microbiota in chronic kidney disease. Nutrients 2019, 11, 496. [CrossRef]

110. Mafra, D.; Gidlund, E.K.; Borges, N.A.; Magliano, D.A.C.; Lindholm, B.; Stenvinkel, P.; von Walden, F. Bioactive food and exercise in chronic kidney disease: Targeting the mitochondria. Eur. J. Clin. Investig. 2018, 48, e13020. [CrossRef]

111. Tao, J.-h.; Zhao, M.; Wang, D.-g.; Yang, C.; Chen, G.-t.; Zhao, X.; Pu, X.-l.; Jiang, S. UPLC-Q-TOF/MS-based screening and identification of two major bioactive components and their metabolites in normal and CKD rat plasma, urine and feces after oral administration of Rehmannia glutinosa Libosch extract. J. Chromatogr. B 2015, 1001, 98-106. [CrossRef]

112. Alvarenga, L.; Cardozo, L.F.; Borges, N.A.; Lindholm, B.; Stenvinkel, P.; Shiels, P.G.; Fouque, D.; Mafra, D. Can nutritional interventions modulate the activation of the NLRP3 inflammasome in chronic kidney disease? Food Res. Int. 2020, 136, 109306. [CrossRef]

113. Skrovankova, S.; Sumczynski, D.; Mlcek, J.; Jurikova, T.; Sochor, J. Bioactive compounds and antioxidant activity in different types of berries. Int. J. Mol. Sci. 2015, 16, 24673-24706. [CrossRef]

114. Serrano, A.; Ros, G.; Nieto, G. Bioactive compounds and extracts from traditional herbs and their potential anti-inflammatory health effects. Medicines 2018, 5, 76. [CrossRef]

115. Torrens, F.; Castellano, G. Immunomodulatory molecules from Himalayan medicinal plants. In Chemistry and Chemical Engineering for Sustainable Development; Apple Academic Press: Oakville, ON, Canada, 2020; p. 267.

116. Xu, J.; Long, Y.; Ni, L.; Yuan, X.; Yu, N.; Wu, R.; Tao, J.; Zhang, Y. Anticancer effect of berberine based on experimental animal models of various cancers: A systematic review and meta-analysis. BMC Cancer 2019, 19, 589. [CrossRef]

117. Li, T.; Wang, P.; Guo, W.; Huang, X.; Tian, X.; Wu, G.; Xu, B.; Li, F.; Yan, C.; Liang, X.J.; et al. Natural Berberine-Based Chinese Herb Medicine Assembled Nanostructures with Modified Antibacterial Application. ACS Nano. 2019, 13, 6770-6781. [CrossRef]

118. Deng, Y.X.; Zhang, X.J.; Shi, Q.Z.; Chen, Y.S.; Qiu, X.M.; Chen, B. Anti-hyperglycemic effects and mechanism of traditional Chinese medicine Huanglian Wan in streptozocin-induced diabetic rats. J. Ethnopharmacol. 2012, 144, 425-432. [CrossRef]

119. Qing, Y.; Dong, X.; Hongli, L.; Yanhui, L. Berberine promoted myocardial protection of postoperative patients through regulating myocardial autophagy. Biomed Pharm. 2018, 105, 1050-1053. [CrossRef] 
120. Singh, A.K.; Singh, S.K.; Nandi, M.K.; Mishra, G.; Maurya, A.; Rai, A.; Rai, G.K.; Awasthi, R.; Sharma, B.; Kulkarni, G.T. Berberine: A Plant-derived Alkaloid with Therapeutic Potential to Combat Alzheimer's disease. Cent. Nerv. Syst. Agents Med. Chem. 2019, 19, 154-170. [CrossRef]

121. Zhu, L.; Zhang, D.; Zhu, H.; Zhu, J.; Weng, S.; Dong, L.; Liu, T.; Hu, Y.; Shen, X. Berberine treatment increases Akkermansia in the gut and improves high-fat diet-induced atherosclerosis in Apoe(-/-) mice. Atherosclerosis 2018, 268, 117-126. [CrossRef]

122. Ehteshamfar, S.M.; Akhbari, M.; Afshari, J.T.; Seyedi, M.; Nikfar, B.; Shapouri-Moghaddam, A.; Ghanbarzadeh, E.; MomtaziBorojeni, A.A. Anti-inflammatory and immune-modulatory impacts of berberine on activation of autoreactive T cells in autoimmune inflammation. J. Cell Mol. Med. 2020, 24, 13573-13588. [CrossRef]

123. Hsu, Y.-Y.; Chen, C.-S.; Wu, S.-N.; Jong, Y.-J.; Lo, Y.-C. Berberine activates Nrf2 nuclear translocation and protects against oxidative damage via a phosphatidylinositol 3-kinase/Akt-dependent mechanism in NSC34 motor neuron-like cells. Eur. J. Pharm. Sci. 2012, 46, 415-425. [CrossRef]

124. Jiang, Q.; Liu, P.; Wu, X.; Liu, W.; Shen, X.; Lan, T.; Xu, S.; Peng, J.; Xie, X.; Huang, H. Berberine attenuates lipopolysaccharideinduced extracelluar matrix accumulation and inflammation in rat mesangial cells: Involvement of NF- $\mathrm{kB}$ signaling pathway. Mol. Cell. Endocrinol. 2011, 331, 34-40. [CrossRef]

125. Jia, L.; Liu, J.; Song, Z.; Pan, X.; Chen, L.; Cui, X.; Wang, M. Berberine suppresses amyloid-beta-induced inflammatory response in microglia by inhibiting nuclear factor-kappaB and mitogen-activated protein kinase signalling pathways. J. Pharm. Pharmacol. 2012, 64, 1510-1521. [CrossRef] [PubMed]

126. Zhu, L.; Han, J.; Yuan, R.; Xue, L.; Pang, W. Berberine ameliorates diabetic nephropathy by inhibiting TLR4/NF-кB pathway. Biol. Res. 2018, 51, 9. [CrossRef] [PubMed]

127. Qin, X.; Jiang, M.; Zhao, Y.; Gong, J.; Su, H.; Yuan, F.; Fang, K.; Yuan, X.; Yu, X.; Dong, H. Berberine protects against diabetic kidney disease via promoting PGC-1 $\alpha$-regulated mitochondrial energy homeostasis. Br. J. Pharmacol. 2020, 177, 3646-3661. [CrossRef] [PubMed]

128. Qin, X.; Zhao, Y.; Gong, J.; Huang, W.; Su, H.; Yuan, F.; Fang, K.; Wang, D.; Li, J.; Zou, X.; et al. Berberine Protects Glomerular Podocytes via Inhibiting Drp1-Mediated Mitochondrial Fission and Dysfunction. Theranostics 2019, 9, 1698-1713. [CrossRef] [PubMed]

129. Li, Z.Y.; Liu, B.; Zhuang, X.J.; Shen, Y.D.; Tian, H.R.; Ji, Y.; Li, L.X.; Liu, F. Effects of berberine on the serum cystatin C levels and urine albumin/creatine ratio in patients with type 2 diabetes mellitus. Zhonghua Yi Xue Za Zhi 2018, 98, 3756-3761. [CrossRef] [PubMed]

130. Jäger, S.; Trojan, H.; Kopp, T.; Laszczyk, M.N.; Scheffler, A. Pentacyclic triterpene distribution in various plants-rich sources for a new group of multi-potent plant extracts. Molecules 2009, 14, 2016-2031. [CrossRef] [PubMed]

131. Seo, D.Y.; Lee, S.R.; Heo, J.-W.; No, M.-H.; Rhee, B.D.; Ko, K.S.; Kwak, H.-B.; Han, J. Ursolic acid in health and disease. Korean J. Physiol. Pharmacol. Off. J. Korean Physiol. Soc. Korean Soc. Pharmacol. 2018, 22, 235-248. [CrossRef] [PubMed]

132. Zhang, Z.; Zhang, H.; Chen, R.; Wang, Z. Oral supplementation with ursolic acid ameliorates sepsis-induced acute kidney injury in a mouse model by inhibiting oxidative stress and inflammatory responses. Mol. Med. Rep. 2018, 17, 7142-7148. [CrossRef]

133. Lu, X.; Fan, Q.; Xu, L.; Li, L.; Yue, Y.; Xu, Y.; Su, Y.; Zhang, D.; Wang, L. Ursolic acid attenuates diabetic mesangial cell injury through the up-regulation of autophagy via miRNA-21/PTEN/Akt/mTOR suppression. PLoS ONE 2015, 10, e0117400. [CrossRef]

134. Jia, Z.; Li, W.; Bian, P.; Yang, L.; Liu, H.; Pan, D.; Dou, Z. Ursolic acid treats renal tubular epithelial cell damage induced by calcium oxalate monohydrate via inhibiting oxidative stress and inflammation. Bioengineered 2021, 12, 5450-5461. [CrossRef]

135. Checker, R.; Sandur, S.K.; Sharma, D.; Patwardhan, R.S.; Jayakumar, S.; Kohli, V.; Sethi, G.; Aggarwal, B.B.; Sainis, K.B. Potent anti-inflammatory activity of ursolic acid, a triterpenoid antioxidant, is mediated through suppression of NF- $\mathrm{BB}, \mathrm{AP}-1$ and NF-AT. PLoS ONE 2012, 7, e31318. [CrossRef]

136. Do Nascimento, P.G.; Lemos, T.L.; Bizerra, A.; Arriaga, Â.; Ferreira, D.A.; Santiago, G.M.; Braz-Filho, R.; Costa, J.G.M. Antibacterial and antioxidant activities of ursolic acid and derivatives. Molecules 2014, 19, 1317-1327. [CrossRef]

137. Ou, K.; Xu, X.; Guan, S.; Zhang, R.; Zhang, X.; Kang, Y.; Wu, J. Nanodrug Carrier Based on Poly (Ursolic Acid) with Self-Anticancer Activity against Colorectal Cancer. Adv. Funct. Mater. 2020, 30, 1907857. [CrossRef]

138. Wang, C.; Gao, Y.; Zhang, Z.; Chen, C.; Chi, Q.; Xu, K.; Yang, L. Ursolic acid protects chondrocytes, exhibits anti-inflammatory properties via regulation of the NF-kB/NLRP3 inflammasome pathway and ameliorates osteoarthritis. Biomed. Pharmacother. 2020, 130, 110568. [CrossRef]

139. Zheng, H.; Feng, H.; Zhang, W.; Han, Y.; Zhao, W. Targeting autophagy by natural product Ursolic acid for prevention and treatment of osteoporosis. Toxicol. Appl. Pharmacol. 2020, 409, 115271. [CrossRef]

140. Thakur, R.; Sharma, A.; Lingaraju, M.C.; Begum, J.; Kumar, D.; Mathesh, K.; Kumar, P.; Singh, T.U.; Kumar, D. Ameliorative effect of ursolic acid on renal fibrosis in adenine-induced chronic kidney disease in rats. Biomed. Pharmacother. 2018, 101, 972-980 [CrossRef]

141. Xu, C.G.; Zhu, X.L.; Wang, W.; Zhou, X.J. Ursolic acid inhibits epithelial-mesenchymal transition in vitro and in vivo. Pharm Biol 2019, 57, 169-175. [CrossRef]

142. Yu, R.; Chen, J.A.; Xu, J.; Cao, J.; Wang, Y.; Thomas, S.S.; Hu, Z. Suppression of muscle wasting by the plant-derived compound ursolic acid in a model of chronic kidney disease. J. Cachexia Sarcopenia Muscle 2017, 8, 327-341. [CrossRef]

143. Ma, T.K.; Xu, L.; Lu, L.X.; Cao, X.; Li, X.; Li, L.L.; Wang, X.; Fan, Q.L. Ursolic Acid Treatment Alleviates Diabetic Kidney Injury By Regulating The ARAP1/AT1R Signaling Pathway. Diabetes Metab. Syndr. Obes. 2019, 12, 2597-2608. [CrossRef] 
144. Bacanli, M.; Aydin, S.; Anlar, H.G.; Çal, T.; Ündeğer Bucurgat, Ü.; Ari, N.; Başaran, A.A.; Başaran, N. Protective Effects of Ursolic Acid in the Kidneys of Diabetic Rats. Turk. J. Pharm. Sci. 2018, 15, 166-170. [CrossRef]

145. Qi, M.Y.; Yang, J.J.; Zhou, B.; Pan, D.Y.; Sun, X. Study on the protective effect of ursolic acid on alloxan-induced diabetic renal injury and its underlying mechanisms. Zhongguo Ying Yong Sheng Li Xue Za Zhi 2014, 30, 445-448. [PubMed]

146. Ding, Y.; Choi, M.E. Autophagy in diabetic nephropathy. J. Endocrinol. 2015, 224, R15-R30. [CrossRef] [PubMed]

147. Xu, L.; Fan, Q.; Wang, X.; Li, L.; Lu, X.; Yue, Y.; Cao, X.; Liu, J.; Zhao, X.; Wang, L. Ursolic acid improves podocyte injury caused by high glucose. Nephrol. Dial. Transpl. 2017, 32, 1285-1293. [CrossRef] [PubMed]

148. Zobeiri, M.; Belwal, T.; Parvizi, F.; Naseri, R.; Farzaei, M.H.; Nabavi, S.F.; Sureda, A.; Nabavi, S.M. Naringenin and its Nanoformulations for Fatty Liver: Cellular Modes of Action and Clinical Perspective. Curr. Pharm. Biotechnol. 2018, 19, 196-205. [CrossRef]

149. Wilcox, L.J.; Borradaile, N.M.; Huff, M.W. Antiatherogenic properties of naringenin, a citrus flavonoid. Cardiovasc. Drug Rev. 1999, 17, 160-178. [CrossRef]

150. Jeandet, P.; Sobarzo-Sánchez, E.; Clément, C.; Nabavi, S.F.; Habtemariam, S.; Nabavi, S.M.; Cordelier, S. Engineering stilbene metabolic pathways in microbial cells. Biotechnol. Adv. 2018, 36, 2264-2283. [CrossRef]

151. Wu, J.; Zhou, T.; Du, G.; Zhou, J.; Chen, J. Modular optimization of heterologous pathways for de novo synthesis of (2S)-naringenin in Escherichia coli. PLoS ONE 2014, 9, e101492. [CrossRef]

152. Kanaze, F.; Bounartzi, M.; Georgarakis, M.; Niopas, I. Pharmacokinetics of the citrus flavanone aglycones hesperetin and naringenin after single oral administration in human subjects. Eur. J. Clin. Nutr. 2007, 61, 472-477. [CrossRef]

153. Pereira-Caro, G.; Polyviou, T.; Ludwig, I.A.; Nastase, A.-M.; Moreno-Rojas, J.M.; Garcia, A.L.; Malkova, D.; Crozier, A. Bioavailability of orange juice (poly) phenols: The impact of short-term cessation of training by male endurance athletes. Am. J. Clin. Nutr. 2017, 106, 791-800. [CrossRef]

154. Den Hartogh, D.J.; Tsiani, E. Antidiabetic Properties of Naringenin: A Citrus Fruit Polyphenol. Biomolecules 2019, 9, 99. [CrossRef]

155. Chen, Y.Y.; Chang, Y.M.; Wang, K.Y.; Chen, P.N.; Hseu, Y.C.; Chen, K.M.; Yeh, K.T.; Chen, C.J.; Hsu, L.S. Naringenin inhibited migration and invasion of glioblastoma cells through multiple mechanisms. Env. Toxicol. 2019, 34, 233-239. [CrossRef]

156. Nouri, Z.; Fakhri, S.; El-Senduny, F.F.; Sanadgol, N.; Abd-ElGhani, G.E.; Farzaei, M.H.; Chen, J.T. On the Neuroprotective Effects of Naringenin: Pharmacological Targets, Signaling Pathways, Molecular Mechanisms, and Clinical Perspective. Biomolecules 2019, 9, 690. [CrossRef]

157. Park, S.; Lim, W.; Bazer, F.W.; Song, G. Naringenin induces mitochondria-mediated apoptosis and endoplasmic reticulum stress by regulating MAPK and AKT signal transduction pathways in endometriosis cells. Mol. Hum. Reprod. 2017, 23, 842-854. [CrossRef]

158. Heidary Moghaddam, R.; Samimi, Z.; Moradi, S.Z.; Little, P.J.; Xu, S.; Farzaei, M.H. Naringenin and naringin in cardiovascular disease prevention: A preclinical review. Eur. J. Pharm. 2020, 887, 173535. [CrossRef]

159. Liu, Y.; An, W.; Gao, A. Protective effects of naringenin in cardiorenal syndrome. J. Surg. Res. 2016, 203, 416-423. [CrossRef]

160. Manchope, M.F.; Calixto-Campos, C.; Coelho-Silva, L.; Zarpelon, A.C.; Pinho-Ribeiro, F.A.; Georgetti, S.R.; Baracat, M.M.; Casagrande, R.; Verri Jr, W.A. Naringenin inhibits superoxide anion-induced inflammatory pain: Role of oxidative stress, cytokines, Nrf-2 and the NO- cGMP- PKG - KATPChannel signaling pathway. PLoS ONE 2016, 11, e0153015. [CrossRef]

161. Pinho-Ribeiro, F.A.; Zarpelon, A.C.; Fattori, V.; Manchope, M.F.; Mizokami, S.S.; Casagrande, R.; Verri, W.A., Jr. Naringenin reduces inflammatory pain in mice. Neuropharmacology 2016, 105, 508-519. [CrossRef]

162. Tsai, S.J.; Huang, C.S.; Mong, M.C.; Kam, W.Y.; Huang, H.Y.; Yin, M.C. Anti-inflammatory and antifibrotic effects of naringenin in diabetic mice. J. Agric. Food Chem. 2012, 60, 514-521. [CrossRef]

163. Chen, L.; Yang, T.; Lu, D.W.; Zhao, H.; Feng, Y.L.; Chen, H.; Chen, D.Q.; Vaziri, N.D.; Zhao, Y.Y. Central role of dysregulation of TGF- $\beta$ /Smad in CKD progression and potential targets of its treatment. Biomed Pharm. 2018, 101, 670-681. [CrossRef]

164. Meng, X.-m.; Zhang, Y.; Huang, X.-R.; Ren, G.-l.; Li, J.; Lan, H.Y. Treatment of renal fibrosis by rebalancing TGF- $\beta /$ Smad signaling with the combination of asiatic acid and naringenin. Oncotarget 2015, 6, 36984-36997. [CrossRef]

165. Kim, Y.-J.; Oh, S.-H.; Ahn, J.-S.; Yook, J.-M.; Kim, C.-D.; Park, S.-H.; Cho, J.-H.; Kim, Y.-L. The Crucial Role of Xanthine Oxidase in CKD Progression Associated with Hypercholesterolemia. Int. J. Mol. Sci. 2020, 21, 7444. [CrossRef] [PubMed]

166. Wang, N.; Tall, A.R. Cholesterol in platelet biogenesis and activation. Blood 2016, 127, 1949-1953. [CrossRef] [PubMed]

167. Chtourou, Y.; Kamoun, Z.; Zarrouk, W.; Kebieche, M.; Kallel, C.; Gdoura, R.; Fetoui, H. Naringenin ameliorates renal and platelet purinergic signalling alterations in high-cholesterol fed rats through the suppression of ROS and NF- $\mathrm{B}$ signaling pathways. Food Funct. 2016, 7, 183-193. [CrossRef] [PubMed]

168. Roy, S.; Ahmed, F.; Banerjee, S.; Saha, U. Naringenin ameliorates streptozotocin-induced diabetic rat renal impairment by downregulation of TGF- $\beta 1$ and IL-1 via modulation of oxidative stress correlates with decreased apoptotic events. Pharm. Biol. 2016, 54, 1616-1627. [CrossRef]

169. Ding, S.; Qiu, H.; Huang, J.; Chen, R.; Zhang, J.; Huang, B.; Zou, X.; Cheng, O.; Jiang, Q. Activation of 20-HETE/PPARs involved in reno-therapeutic effect of naringenin on diabetic nephropathy. Chem. Biol. Interact. 2019, 307, 116-124. [CrossRef]

170. Venditti, A.; Frezza, C.; Sciubba, F.; Serafini, M.; Bianco, A.; Cianfaglione, K.; Lupidi, G.; Quassinti, L.; Bramucci, M.; Maggi, F. Volatile components, polar constituents and biological activity of tansy daisy (Tanacetum macrophyllum (Waldst. et Kit.) Schultz Bip.). Ind. Crop. Prod. 2018, 118, 225-235. [CrossRef] 
171. Sharifi-Rad, M.; Nazaruk, J.; Polito, L.; Morais-Braga, M.F.B.; Rocha, J.E.; Coutinho, H.D.M.; Salehi, B.; Tabanelli, G.; Montanari, C.; del Mar Contreras, M. Matricaria genus as a source of antimicrobial agents: From farm to pharmacy and food applications. Microbiol. Res. 2018, 215, 76-88. [CrossRef]

172. Venditti, A.; Guarcini, L.; Bianco, A.; Rosselli, S.; Bruno, M.; Senatore, F. Phytochemical analysis of Achillea ligustica all. from Lipari Island (Aeolian islands). Nat. Prod. Res. 2016, 30, 912-919. [CrossRef]

173. Ornano, L.; Venditti, A.; Donno, Y.; Sanna, C.; Ballero, M.; Bianco, A. Phytochemical analysis of non-volatile fraction of Artemisia caerulescens subsp. densiflora (Viv.)(Asteraceae), an endemic species of La Maddalena Archipelago (Sardinia-Italy). Nat. Prod. Res. 2016, 30, 920-925. [CrossRef]

174. Salehi, B.; Venditti, A.; Sharifi-Rad, M.; Kregiel, D.; Sharifi-Rad, J.; Durazzo, A.; Lucarini, M.; Santini, A.; Souto, E.B.; Novellino, E. The therapeutic potential of apigenin. Int. J. Mol. Sci. 2019, 20, 1305. [CrossRef]

175. Lee, H.; Kim, B.G.; Kim, M.; Ahn, J.H. Biosynthesis of Two Flavones, Apigenin and Genkwanin, in Escherichia coli. J. Microbiol. Biotechnol. 2015, 25, 1442-1448. [CrossRef]

176. Shukla, S.; Gupta, S. Molecular targets for apigenin-induced cell cycle arrest and apoptosis in prostate cancer cell xenograft. Mol. Cancer Ther. 2006, 5, 843-852. [CrossRef]

177. Suh, K.S.; Oh, S.; Woo, J.-T.; Kim, S.-W.; Kim, J.-W.; Kim, Y.S.; Chon, S. Apigenin attenuates 2-deoxy-D-ribose-induced oxidative cell damage in HIT-T15 pancreatic $\beta$-cells. Biol. Pharm. Bull. 2012, 35, 121-126. [CrossRef]

178. Kang, C.H.; Molagoda, I.M.N.; Choi, Y.H.; Park, C.; Moon, D.O.; Kim, G.Y. Apigenin promotes TRAIL-mediated apoptosis regardless of ROS generation. Food Chem. Toxicol. 2018, 111, 623-630. [CrossRef]

179. Lee, J.-H.; Zhou, H.Y.; Cho, S.Y.; Kim, Y.S.; Lee, Y.S.; Jeong, C.S. Anti-inflammatory mechanisms of apigenin: Inhibition of cyclooxygenase-2 expression, adhesion of monocytes to human umbilical vein endothelial cells, and expression of cellular adhesion molecules. Arch. Pharmacal. Res. 2007, 30, 1318-1327. [CrossRef]

180. Huang, C.-S.; Lii, C.-K.; Lin, A.-H.; Yeh, Y.-W.; Yao, H.-T.; Li, C.-C.; Wang, T.-S.; Chen, H.-W. Protection by chrysin, apigenin, and luteolin against oxidative stress is mediated by the Nrf2-dependent up-regulation of heme oxygenase 1 and glutamate cysteine ligase in rat primary hepatocytes. Arch. Toxicol. 2013, 87, 167-178. [CrossRef]

181. Paredes-Gonzalez, X.; Fuentes, F.; Jeffery, S.; Saw, C.L.L.; Shu, L.; Su, Z.Y.; Kong, A.N.T. Induction of NRF2-mediated gene expression by dietary phytochemical flavones apigenin and luteolin. Biopharm. Drug Dispos. 2015, 36, 440-451. [CrossRef]

182. Wei, X.; Gao, P.; Pu, Y.; Li, Q.; Yang, T.; Zhang, H.; Xiong, S.; Cui, Y.; Li, L.; Ma, X. Activation of TRPV4 by dietary apigenin antagonizes renal fibrosis in deoxycorticosterone acetate (DOCA)-salt-induced hypertension. Clin. Sci. 2017, 131, 567-581. [CrossRef]

183. Li, N.; Wang, Z.; Sun, T.; Lei, Y.; Liu, X.; Li, Z. Apigenin Alleviates Renal Fibroblast Activation through AMPK and ERK Signaling Pathways In Vitro. Curr. Pharm. Biotechnol. 2020, 21, 1107-1118. [CrossRef]

184. Vera, M.; Torramade-Moix, S.; Martin-Rodriguez, S.; Cases, A.; Cruzado, J.M.; Rivera, J.; Escolar, G.; Palomo, M.; Diaz-Ricart, M. Antioxidant and anti-inflammatory strategies based on the potentiation of glutathione peroxidase activity prevent endothelial dysfunction in chronic kidney disease. Cell Physiol. Biochem. 2018, 51, 1287-1300. [CrossRef]

185. Morigi, M.; Perico, L.; Benigni, A. Sirtuins in Renal Health and Disease. J. Am. Soc. Nephrol. 2018, 29, 1799-1809. [CrossRef]

186. Cantó, C.; Menzies, K.J.; Auwerx, J. NAD(+) Metabolism and the Control of Energy Homeostasis: A Balancing Act between Mitochondria and the Nucleus. Cell Metab. 2015, 22, 31-53. [CrossRef]

187. Ogura, Y.; Kitada, M.; Xu, J.; Monno, I.; Koya, D. CD38 inhibition by apigenin ameliorates mitochondrial oxidative stress through restoration of the intracellular NAD+/NADH ratio and Sirt3 activity in renal tubular cells in diabetic rats. Aging 2020, 12, 11325. [CrossRef]

188. Li, P.; Bukhari, S.N.A.; Khan, T.; Chitti, R.; Bevoor, D.B.; Hiremath, A.R.; SreeHarsha, N.; Singh, Y.; Gubbiyappa, K.S. ApigeninLoaded Solid Lipid Nanoparticle Attenuates Diabetic Nephropathy Induced by Streptozotocin Nicotinamide Through Nrf2/HO1/NF-kB Signalling Pathway. Int. J. Nanomed. 2020, 15, 9115-9124. [CrossRef]

189. Spagnuolo, C.; Russo, G.L.; Orhan, I.E.; Habtemariam, S.; Daglia, M.; Sureda, A.; Nabavi, S.F.; Devi, K.P.; Loizzo, M.R.; Tundis, R.; et al. Genistein and cancer: Current status, challenges, and future directions. Adv. Nutr. 2015, 6, 408-419. [CrossRef]

190. Ye, L.; Chan, M.Y.; Leung, L.K. The soy isoflavone genistein induces estrogen synthesis in an extragonadal pathway. Mol. Cell. Endocrinol. 2009, 302, 73-80. [CrossRef]

191. Yang, Z.; Zhu, W.; Gao, S.; Xu, H.; Wu, B.; Kulkarni, K.; Singh, R.; Tang, L.; Hu, M. Simultaneous determination of genistein and its four phase II metabolites in blood by a sensitive and robust UPLC-MS/MS method: Application to an oral bioavailability study of genistein in mice. J. Pharm. Biomed. Anal. 2010, 53, 81-89. [CrossRef]

192. Mukund, V.; Mukund, D.; Sharma, V.; Mannarapu, M.; Alam, A. Genistein: Its role in metabolic diseases and cancer. Crit Rev Oncol. Hematol. 2017, 119, 13-22. [CrossRef]

193. Thangavel, P.; Puga-Olguín, A.; Rodríguez-Landa, J.F.; Zepeda, R.C. Genistein as Potential Therapeutic Candidate for Menopausal Symptoms and Other Related Diseases. Molecules 2019, 24, 3892. [CrossRef]

194. Wang, W.; Chen, J.; Mao, J.; Li, H.; Wang, M.; Zhang, H.; Li, H.; Chen, W. Genistein Ameliorates Non-alcoholic Fatty Liver Disease by Targeting the Thromboxane A(2) Pathway. J. Agric. Food Chem. 2018, 66, 5853-5859. [CrossRef]

195. Park, C.; Cha, H.J.; Lee, H.; Hwang-Bo, H.; Ji, S.Y.; Kim, M.Y.; Hong, S.H.; Jeong, J.W.; Han, M.H.; Choi, S.H.; et al. Induction of G2/M Cell Cycle Arrest and Apoptosis by Genistein in Human Bladder Cancer T24 Cells through Inhibition of the ROS-Dependent PI3k/Akt Signal Transduction Pathway. Antioxidants 2019, 8, 327. [CrossRef] [PubMed] 
196. Lu, R.; Zheng, Z.; Yin, Y.; Jiang, Z. Genistein prevents bone loss in type 2 diabetic rats induced by streptozotocin. Food Nutr. Res. 2020, 64, 10-29219. [CrossRef] [PubMed]

197. Luo, Y.; Wang, S.-x.; Zhou, Z.-q.; Wang, Z.; Zhang, Y.-g.; Zhang, Y.; Zhao, P. Apoptotic effect of genistein on human colon cancer cells via inhibiting the nuclear factor-kappa B (NF-кB) pathway. Tumor. Biol. 2014, 35, 11483-11488. [CrossRef] [PubMed]

198. Shafiee, G.; Saidijam, M.; Tavilani, H.; Ghasemkhani, N.; Khodadadi, I. Genistein induces apoptosis and inhibits proliferation of HT29 colon cancer cells. Int. J. Mol. Cell. Med. 2016, 5, 178. [PubMed]

199. Braxas, H.; Rafraf, M.; Hasanabad, S.K.; Jafarabadi, M.A. Effectiveness of genistein supplementation on metabolic factors and antioxidant status in postmenopausal women with type 2 diabetes mellitus. Can. J. Diabetes 2019, 43, 490-497. [CrossRef] [PubMed]

200. Hwang, J.-T.; Lee, Y.-K.; Shin, J.-I.; Parkb, O.J. Anti-inflammatory and Anticarcinogenic Effect of Genistein Alone or in Combination with Capsaicin in TPA-Treated Rat Mammary Glands or Mammary Cancer Cell Line. In Natural Compounds and Their Role in Apoptotic Cell Signaling Pathways; Blackwell Publishing on behalf of New York Academy of Sciences: Boston, MS, USA, 2009; Volume 1171, p. 415.

201. Li, J.; Li, J.; Yue, Y.; Hu, Y.; Cheng, W.; Liu, R.; Pan, X.; Zhang, P. Genistein suppresses tumor necrosis factor $\alpha$-induced inflammation via modulating reactive oxygen species/Akt/nuclear factor $\mathrm{kB}$ and adenosine monophosphate-activated protein kinase signal pathways in human synoviocyte MH7A cells. Drug Des. Dev. Ther. 2014, 8, 315. [CrossRef] [PubMed]

202. Sutrisno, S.; Aprina, H.; Simanungkalit, H.M.; Andriyani, A.; Barlianto, W.; Sujuti, H.; Santoso, S.; Dwijayasa, P.M.; Wahyuni, E.S.; Mustofa, E. Genistein modulates the estrogen receptor and suppresses angiogenesis and inflammation in the murine model of peritoneal endometriosis. J. Tradit. Complementary Med. 2018, 8, 278-281. [CrossRef]

203. Jia, Q.; Yang, R.; Liu, X.F.; Ma, S.F.; Wang, L. Genistein attenuates renal fibrosis in streptozotocin-induced diabetic rats. Mol. Med. Rep. 2019, 19, 423-431. [CrossRef]

204. Yuan, W.J.; Jia, F.Y.; Meng, J.Z. Effects of genistein on secretion of extracellular matrix components and transforming growth factor beta in high-glucose-cultured rat mesangial cells. J. Artif. Organs. 2009, 12, 242-246. [CrossRef]

205. Lin, T.-A.; Wu, V.C.-C.; Wang, C.-Y. Autophagy in Chronic Kidney Diseases. Cells 2019, 8, 61. [CrossRef]

206. Wang, Y.; Li, Y.; Zhang, T.; Chi, Y.; Liu, M.; Liu, Y. Genistein and Myd88 Activate Autophagy in High Glucose-Induced Renal Podocytes In Vitro. Med. Sci. Monit. 2018, 24, 4823-4831. [CrossRef]

207. Kim, M.J.; Lim, Y. Protective effect of short-term genistein supplementation on the early stage in diabetes-induced renal damage. Mediat. Inflamm. 2013, 2013, 510212. [CrossRef]

208. Asmis, R.; Stevens, J.; Begley, J.G.; Grimes, B.; Van Zant, G.; Fanti, P. The isoflavone genistein inhibits LPS-stimulated TNFalpha, but not IL-6 expression in monocytes from hemodialysis patients and healthy subjects. Clin. Nephrol. 2006, 65, 267-275. [CrossRef]

209. Vázquez-Flores, L.; Casas-Grajales, S.; Hernández-Aquino, E.; Vargas-Pozada, E.; Muriel, P. Antioxidant, antiinflammatory, and antifibrotic properties of quercetin in the liver. In Liver Pathophysiology; Elsevier: Amsterdam, The Netherlands, 2017; pp. 653-674.

210. Singh, H.; Kaur, P.; Kaur, P.; Muthuraman, A.; Singh, G.; Kaur, M. Investigation of therapeutic potential and molecular mechanism of vitamin P and digoxin in I/R-induced myocardial infarction in rat. Naunyn-Schmiedeberg's Arch. Pharmacol. 2015, 388, 565-574. [CrossRef]

211. Ganeshpurkar, A.; Saluja, A.K. The pharmacological potential of rutin. Saudi. Pharm. J. 2017, 25, 149-164. [CrossRef]

212. Enogieru, A.B.; Haylett, W.; Hiss, D.C.; Bardien, S.; Ekpo, O.E. Rutin as a potent antioxidant: Implications for neurodegenerative disorders. Oxidative Med. Cell. Longev. 2018, 2018, 6241017. [CrossRef]

213. Yang, J.; Guo, J.; Yuan, J. In vitro antioxidant properties of rutin. LWT-Food Sci. Technol. 2008, 41, 1060-1066. [CrossRef]

214. Chen, L.-Y.; Huang, C.-N.; Liao, C.-K.; Chang, H.-M.; Kuan, Y.-H.; Tseng, T.-J.; Yen, K.-J.; Yang, K.-L.; Lin, H.-C. Effects of Rutin on Wound Healing in Hyperglycemic Rats. Antioxidants 2020, 9, 1122. [CrossRef]

215. Çelik, H.; Kandemir, F.M.; Caglayan, C.; Özdemir, S.; Çomaklı, S.; Kucukler, S.; Yardım, A. Neuroprotective effect of rutin against colistin-induced oxidative stress, inflammation and apoptosis in rat brain associated with the CREB/BDNF expressions. Mol. Biol. Rep. 2020, 47, 2023-2034. [CrossRef]

216. Su, S.; Li, X.; Li, S.; Ming, P.; Huang, Y.; Dong, Y.; Ding, H.; Feng, S.; Li, J.; Wang, X. Rutin protects against lipopolysaccharideinduced mastitis by inhibiting the activation of the NF- $\mathrm{KB}$ signaling pathway and attenuating endoplasmic reticulum stress. Inflammopharmacology 2019, 27, 77-88. [CrossRef]

217. Diwan, V.; Brown, L.; Gobe, G.C. The flavonoid rutin improves kidney and heart structure and function in an adenine-induced rat model of chronic kidney disease. J. Funct. Foods 2017, 33, 85-93. [CrossRef]

218. Han, Y.; Lu, J.-S.; Xu, Y.; Zhang, L.; Hong, B.-F. Rutin ameliorates renal fibrosis and proteinuria in 5/6-nephrectomized rats by anti-oxidation and inhibiting activation of TGF $\beta 1$-smad signaling. Int. J. Clin. Exp. Pathol. 2015, 8, 4725-4734. [PubMed]

219. Wang, B.; Liu, D.; Zhu, Q.H.; Li, M.; Chen, H.; Guo, Y.; Fan, L.P.; Yue, L.S.; Li, L.Y.; Zhao, M. Rutin ameliorates kidney interstitial fibrosis in rats with obstructive nephropathy. Int. Immunopharmacol. 2016, 35, 77-84. [CrossRef] [PubMed]

220. Al-Rejaie, S.S.; Abuohashish, H.M.; Alkhamees, O.A.; Aleisa, A.M.; Alroujayee, A.S. Gender difference following high cholesterol diet induced renal injury and the protective role of rutin and ascorbic acid combination in Wistar albino rats. Lipids Health Dis. 2012, 11, 41. [CrossRef]

221. Wang, X.; Zhao, X.; Feng, T.; Jin, G.; Li, Z. Rutin Prevents High Glucose-Induced Renal Glomerular Endothelial Hyperpermeability by Inhibiting the ROS/Rhoa/ROCK Signaling Pathway. Planta. Med. 2016, 82, 1252-1257. [CrossRef] 
222. Ganesan, D.; Holkar, A.; Albert, A.; Paul, E.; Mariakuttikan, J.; Sadasivam Selvam, G. Combination of ramipril and rutin alleviate alloxan induced diabetic nephropathy targeting multiple stress pathways in vivo. Biomed Pharm. 2018, 108, 1338-1346. [CrossRef]

223. Ganesan, D.; Albert, A.; Paul, E.; Ananthapadmanabhan, K.; Andiappan, R.; Sadasivam, S.G. Rutin ameliorates metabolic acidosis and fibrosis in alloxan induced diabetic nephropathy and cardiomyopathy in experimental rats. Mol Cell Biochem 2020, 471, 41-50. [CrossRef]

224. Hao, H.H.; Shao, Z.M.; Tang, D.Q.; Lu, Q.; Chen, X.; Yin, X.X.; Wu, J.; Chen, H. Preventive effects of rutin on the development of experimental diabetic nephropathy in rats. Life Sci. 2012, 91, 959-967. [CrossRef]

225. Neto, R.T.; Santos, S.A.; Oliveira, J.; Silvestre, A.J. Biorefinery of high polymerization degree proanthocyanidins in the context of circular economy. Ind. Crop. Prod. 2020, 151, 112450. [CrossRef]

226. Zhou, H.-C.; Lin, Y.-M.; Li, Y.-Y.; Li, M.; Wei, S.-D.; Chai, W.-M.; Tam, N.F.-y. Antioxidant properties of polymeric proanthocyanidins from fruit stones and pericarps of Litchi chinensis Sonn. Food Res. Int. 2011, 44, 613-620. [CrossRef]

227. Lee, J.-W.; Kim, Y.I.; Kim, Y.; Choi, M.; Min, S.; Joo, Y.H.; Yim, S.-V.; Chung, N. Grape seed proanthocyanidin inhibits inflammatory responses in hepatic stellate cells by modulating the MAPK, Akt and NF-кB signaling pathways. Int. J. Mol. Med. 2017, 40, 226-234. [CrossRef]

228. Chen, X.; Xiong, J.; Huang, S.; Li, X.; Zhang, Y.; Zhang, L.; Wang, F. Analytical profiling of proanthocyanidins from Acacia mearnsii bark and in vitro assessment of antioxidant and antidiabetic potential. Molecules 2018, 23, 2891. [CrossRef]

229. Zhou, Q.; Han, X.; Li, R.; Zhao, W.; Bai, B.; Yan, C.; Dong, X. Anti-atherosclerosis of oligomeric proanthocyanidins from Rhodiola rosea on rat model via hypolipemic, antioxidant, anti-inflammatory activities together with regulation of endothelial function. Phytomedicine 2018, 51, 171-180. [CrossRef]

230. Karthikeyan, K.; Bai, B.S.; Devaraj, S.N. Efficacy of grape seed proanthocyanidins on cardioprotection during isoproterenolinduced myocardial injury in rats. J. Cardiovasc. Pharmacol. 2009, 53, 109-115. [CrossRef]

231. Kruger, M.J.; Davies, N.; Myburgh, K.H.; Lecour, S. Proanthocyanidins, anthocyanins and cardiovascular diseases. Food Res. Int. 2014, 59, 41-52. [CrossRef]

232. Zhan, J.; Wang, K.; Zhang, C.; Zhang, C.; Li, Y.; Zhang, Y.; Chang, X.; Zhou, Q.; Yao, Y.; Liu, Y. GSPE inhibits HMGB1 release, attenuating renal IR-induced acute renal injury and chronic renal fibrosis. Int. J. Mol. Sci. 2016, 17, 1647. [CrossRef]

233. Wang, K.; Wei, H.; Zhan, J.; Liang, X.; Zhang, C.; Liu, Y.; Xu, G. GSPE alleviates renal fibrosis by inhibiting the activation of C3/HMGB1/TGF- $\beta 1$ pathway. Chem. Biol. Interact. 2020, 316, 108926. [CrossRef]

234. Li, X.; Xiao, Y.; Gao, H.; Li, B.; Xu, L.; Cheng, M.; Jiang, B.; Ma, Y. Grape seed proanthocyanidins ameliorate diabetic nephropathy via modulation of levels of AGE, RAGE and CTGF. Nephron Exp. Nephrol. 2009, 111, e31-e41. [CrossRef]

235. Sayed, A.A. Thymoquinone and proanthocyanidin attenuation of diabetic nephropathy in rats. Eur. Rev. Med. Pharm. Sci. 2012, 16, 808-815. [CrossRef]

236. Ding, Y.; Li, H.; Li, Y.; Liu, D.; Zhang, L.; Wang, T.; Liu, T.; Ma, L. Protective Effects of Grape Seed Proanthocyanidins on the Kidneys of Diabetic Rats through the Nrf2 Signalling Pathway. Evid. Based Complementary Altern. Med. 2020, $2020,5205903$. [CrossRef]

237. Bao, L.; Zhang, Z.; Dai, X.; Ding, Y.; Jiang, Y.; Li, Y.; Li, Y. Effects of grape seed proanthocyanidin extract on renal injury in type 2 diabetic rats. Mol. Med. Rep. 2015, 11, 645-652. [CrossRef]

238. Gao, Z.; Liu, G.; Hu, Z.; Shi, W.; Chen, B.; Zou, P.; Li, X. Grape seed proanthocyanidins protect against streptozotocin-induced diabetic nephropathy by attenuating endoplasmic reticulum stress-induced apoptosis. Mol. Med. Rep. 2018, 18, 1447-1454. [CrossRef]

239. Izumi, T.; Terauchi, M. The Diverse Efficacy of Food-Derived Proanthocyanidins for Middle-Aged and Elderly Women. Nutrients 2020, 12, 3833. [CrossRef]

240. Ivey, K.L.; Lewis, J.R.; Lim, W.H.; Lim, E.M.; Hodgson, J.M.; Prince, R.L. Associations of proanthocyanidin intake with renal function and clinical outcomes in elderly women. PLoS ONE 2013, 8, e71166.

241. Odai, T.; Terauchi, M.; Kato, K.; Hirose, A.; Miyasaka, N. Effects of Grape Seed Proanthocyanidin Extract on Vascular Endothelial Function in Participants with Prehypertension: A Randomized, Double-Blind, Placebo-Controlled Study. Nutrients 2019, 11, 2844. [CrossRef]

242. Ríos, J.L.; Máñez, S. New Pharmacological Opportunities for Betulinic Acid. Planta Med. 2018, 84, 8-19. [CrossRef]

243. Karagöz, A.; Leidenberger, M.; Hahn, F.; Hampel, F.; Friedrich, O.; Marschall, M.; Kappes, B.; Tsogoeva, S.B. Synthesis of new betulinic acid/betulin-derived dimers and hybrids with potent antimalarial and antiviral activities. Bioorg. Med. Chem. 2019, 27, 110-115. [CrossRef]

244. Nicolov, M.; Ghiulai, R.M.; Voicu, M.; Mioc, M.; Duse, A.O.; Roman, R.; Ambrus, R.; Zupko, I.; Moaca, E.A.; Coricovac, D.E.; et al. Cocrystal Formation of Betulinic Acid and Ascorbic Acid: Synthesis, Physico-Chemical Assessment, Antioxidant, and Antiproliferative Activity. Front. Chem. 2019, 7, 92. [CrossRef]

245. Oriakhi, K.; Uadia, P.O.; Shaheen, F.; Jahan, H.; Ibeji, C.U.; Iqbal, C.M. Isolation, characterization, and hepatoprotective properties of betulinic acid and ricinine from Tetracarpidium conophorum seeds (Euphorbiaceae). J. Food. Biochem. 2020, 45, e13288. [CrossRef]

246. Lee, S.; Jung, K.; Lee, D.; Lee, S.R.; Lee, K.R.; Kang, K.S.; Kim, K.H. Protective effect and mechanism of action of lupane triterpenes from Cornus walteri in cisplatin-induced nephrotoxicity. Bioorg. Med. Chem. Lett. 2015, 25, 5613-5618. [CrossRef]

247. Ekuadzi, E.; Biney, R.P.; Benneh, C.K.; Osei Amankwaa, B.; Jato, J. Antiinflammatory properties of betulinic acid and xylopic acid in the carrageenan-induced pleurisy model of lung inflammation in mice. Phytother. Res. 2018, 32, 480-487. [CrossRef] [PubMed] 
248. Lee, D.; Lee, S.R.; Kang, K.S.; Ko, Y.; Pang, C.; Yamabe, N.; Kim, K.H. Betulinic Acid Suppresses Ovarian Cancer Cell Proliferation through Induction of Apoptosis. Biomolecules 2019, 9, 257. [CrossRef] [PubMed]

249. Zheng, Y.; Liu, P.; Wang, N.; Wang, S.; Yang, B.; Li, M.; Chen, J.; Situ, H.; Xie, M.; Lin, Y.; et al. Betulinic Acid Suppresses Breast Cancer Metastasis by Targeting GRP78-Mediated Glycolysis and ER Stress Apoptotic Pathway. Oxid. Med. Cell Longev. 2019, 2019, 8781690. [CrossRef] [PubMed]

250. Hordyjewska, A.; Ostapiuk, A.; Horecka, A.; Kurzepa, J. Betulin and betulinic acid: Triterpenoids derivatives with a powerful biological potential. Phytochem. Rev. 2019, 18, 929-951. [CrossRef]

251. Wu, J.; Niu, Y.; Bakur, A.; Li, H.; Chen, Q. Cell-free production of pentacyclic triterpenoid compound betulinic acid from betulin by the engineered Saccharomyces cerevisiae. Molecules 2017, 22, 1075. [CrossRef]

252. Fan, R.; Hu, P.-c.; Wang, Y.; Lin, H.-y.; Su, K.; Feng, X.-s.; Wei, L.; Yang, F. Betulinic acid protects mice from cadmium chlorideinduced toxicity by inhibiting cadmium-induced apoptosis in kidney and liver. Toxicol. Lett. 2018, 299, 56-66. [CrossRef]

253. Prakash, B.; Surendran, A.; Chandraprabha, V.R.; Pettamanna, A.; Nair, H.N.R. Betulinic acid, natural pentacyclic triterpenoid prevents arsenic-induced nephrotoxicity in male Wistar rats. Comp. Clin. Pathol. 2018, 27, 37-44. [CrossRef]

254. Noushida, N.; Shenoy, P.J.; Rao, R.R.; Teerthanath, S. Nephroprotective activity of betulinic acid in gentamicin induced murine model of Renotoxicity. Res. J. Pharm. Technol. 2020, 13, 1391-1396. [CrossRef]

255. Sharma, A.; Thakur, R.; Lingaraju, M.C.; Kumar, D.; Mathesh, K.; Telang, A.G.; Singh, T.U.; Kumar, D. Betulinic acid attenuates renal fibrosis in rat chronic kidney disease model. Biomed. Pharmacother. 2017, 89, 796-804. [CrossRef]

256. Wang, S.; Yang, Z.; Xiong, F.; Chen, C.; Chao, X.; Huang, J.; Huang, H. Betulinic acid ameliorates experimental diabetic-induced renal inflammation and fibrosis via inhibiting the activation of NF-кB signaling pathway. Mol. Cell. Endocrinol. 2016, 434, 135-143. [CrossRef]

257. Xie, R.; Zhang, H.; Wang, X.-z.; Yang, X.-z.; Wu, S.-n.; Wang, H.-g.; Shen, P.; Ma, T.-h. The protective effect of betulinic acid (BA) diabetic nephropathy on streptozotocin (STZ)-induced diabetic rats. Food Funct. 2017, 8, 299-306. [CrossRef]

258. Sutariya, B.; Taneja, N.; Saraf, M. Betulinic acid, isolated from the leaves of Syzygium cumini (L.) Skeels, ameliorates the proteinuria in experimental membranous nephropathy through regulating Nrf2/NF-кB pathways. Chem. Biol. Interact. 2017, $274,124-137$. [CrossRef] 